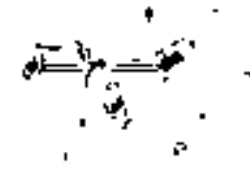

c00-1407-15

THE UN I VERS I T OF M C C I G A COLLEGE OF ENGINEARING

Department of Meteorology and Oceanography

\title{
MASTER
}

\section{CFst RHCES}

und 13

н. $3.00 ;$ w.

Frogress Report No. 3

RAIN SCAVENGING STUDIES

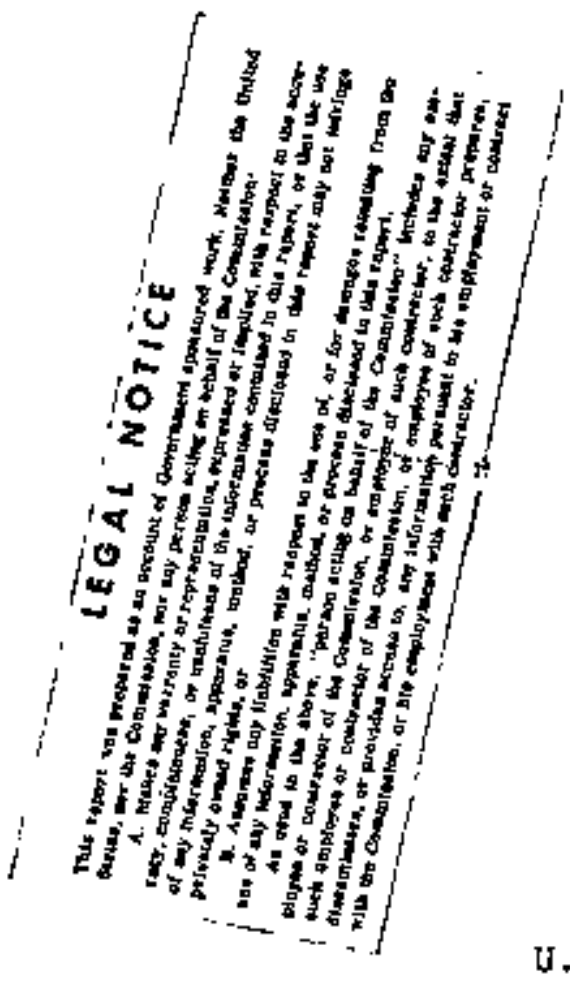

A. Nelson Dingle

and

Donald F. Getz

ORA Project 06967

under contract with:

U. S. ATOMIC ENERGY COMISSION

CONTRACT NO. AT(11-1)-1407

ARGONES, ILLINOIS

$s$

adminsstered through:

OFFICE OF RESEARCH ADMTNISTRATION

ANN ARBOR

May 1967 


\section{DISCLAIMER}

This report was prepared as an account of work sponsored by an agency of the United States Government. Neither the United States Government nor any agency Thereot, nor any of their employees, makes any warranty, express or implied, or assumes any legal liability or responsibility for the accuracy, completeness, or usefulness of any information, apparatus, product, or process disclosed, or represents that its use would not infringe privately owned rights. Reference herein to any specific commercial product, process, or service by trade name, trademark, manufacturer, or otherwise does not necessarily constitute or imply its endorsement, recommendation, or favoring by the United States Government or any agency thereof. The views and opinions of authors expressed herein do not necessarlly state or reflect those of the United States Government or any agency thereof. 


\section{DISCLAIMER}

Portions of this document may be illegible in electronic image products. Images are produced from the best available original document. 
TABLE OF CONTENTS

LIST OF ILLUSTRATIONS

Page

AESTRACT

$\mathbf{v}$

$\mathbf{v 1}$

I. FIELD DATA COLLECTION AND ANALYSIS 1

A. Introduction

B. Data Recording and Reduction Systems

1. The magnetic tape dats recording and decodins system (V. L. Larrowe)

2. Drop size data reduction (F. V. Brock)

3. Automatic reduction and tabulation of other data components

c. Resulta

1. Ralnfall and sample deta

2. Radloactivity analysis

3. Deuterium and tritium analyaes

4. Follen analysis

1

4

4

15

17

17

17

18
$18 \sim$

25

26

26

27

27

28

29

29

30

34

III. MOBILE SAMPLIMG

A. A Facility of High Mobilfty flaving the Principal Function of Procuring Rain Samples from Shower Systerns of Interest

1. Function: to obtain sequential sanples in severe storms having a good time resolution at a point

2. Function: to obtain distributed samples using portable samplers in controlled tracer studies

B. A Comprehensive Rain-Sampling and observing Facility of Lesser Hobility, Capable of Operating Over an Extended Area in Association with Suitable Radar Coverage and Other Complementary Support By others

c. Contunications 
TV. PRESEHTATIONS AND PUBLICATIONS

A. Presentations

37

B. Publications

38

C. Abstracts of Papers in Press

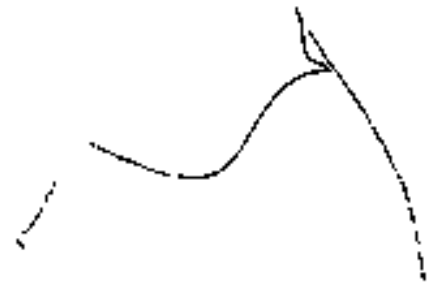




\section{LIST OF IILUSTRATIONS}

Table

Page

I. Log of Observations - 1966

II. Results of Analyses for Beta-Radioactivity, Tritium, and Deuterium

III. Neutron Activation Data for Indium and silver

F1gure

1. Information flow in channel 1 of the recording system.

2. Data recording system for track $\$ 4$.

3. Data encoding and recording systent.

4. Data playback and decoding aystem.

5. The event decoder.

6. Gross beta-radionctivity curtes for rain samples traken in Apr1l-May, 1966.

7. Use of mobile units (2) with portable samplers, exanple 1.

8. Use of mobile units (2) with portable samplers, example 2 .

9. Use of mobile units (2) with portable samplers, example 3 . 
During 1966-1967 a great deal of effort has been directed toward the development of an efficient data-recording and data-reduction system designed to use $1 / 4-i n$. nagnetic tape and to be processed by means of the analog-digital hybrid computer facility of the Defartment of Meteorology and Ocenography. A second developmental effort demanding of much time has been that toward the launching of pilot experiments in the use of controlled tracers for the study of (a) severe atorins clrculation systems and (b) the processes of rain scavenging. Development of a mobile sampling system suitable for use in the tracer experiments as well as in other field projects working on precipitstion was a third and somewhat less demanding develowmental activity of the yeer. Details of the chemical and radiochemical procedures for the evaluation of tracer materlal ( In-115 $+\mathrm{o}^{n^{\prime}}+\operatorname{In}-116 \mathrm{~m}$ ) were also worked out prior to the beginning of the field experiment phase 1 May - 15 June, 1967.

In addition an effort was made during the year to communicate our techniques and results to the profession by means of papers at several conferences and by the preparation of material for publication. 


\section{FIFHD DATA COLEDCTION AND ATHALYSIS}

\section{A. INTRODUCTION}

The University of N1chigan atation at Chickasha, Oklahoma, was activated for rain sampling and data collection by 15 April 1966 and operated until 1 June 1966. The rain events for which data were collected during this period are indicated in Table I.

Again, the kind of weather event that produced the most extensive set of date was entirely different fron those docuaented in previous years. Th1a was a very persistent light rain for the most part, containing some moderate to heavy intensities in its earlier portions, but mostly giving intensities below $10 \mathrm{~mm} / \mathrm{hr}$ (Teble II).

The NSSL capability wa enhaned considerably for the fleld operation period. Among other items, installation was set up at the Chickasha Airport, approximately 1 mile from our main station, to take frequent rawinsondes, and to record zenith- and near-zenith-pointing doppler radar returns. Both of these components of information are of importance to our analyses, the rawinsondes supplyling the needed atmospheric measurements for the water budget studies, and the doppler radar data supplying estimates of the precipitation particle sizes at varjous altitudes. It is anticipated that these data, taken together with our ground level drop size data, will supply all the information needed totrace the processes of drop growth and the associated and related scavenging processes from the top of the precipitation-generating region to the ground.

To support our projected water budget analyses, we undertook this year, in addition to our established program of rain aamping, to obtain rain samples from a net of ten stations formerly operated by the University of oklahoma. These stations were kindly made avallable for our use by Professox Saucier. our objective was simply to collect a sample for each rainfall fron each of the ten stations, Although a division of the rainfalls into subsamples would be useful to us, we could not field enough manpower to maintain, service, and operate the automatic samplers within our budget. Because of the character of the rains whlch occurred, this effort wa only pertially successful.

Special samples were procured at the main sampling station for deuterium and tritiun analysis by Dr. Dieter thisalt of NCAR. Because it was required that these samples have no chemicals added to them, each was taken as a fraction of the flow from the collecting funnels and bottled separstely. Th1s procedure was neceasary because of our previously adopted practice of priming 
TABLE I

LOG OP OBSBRVATIONS - 1966

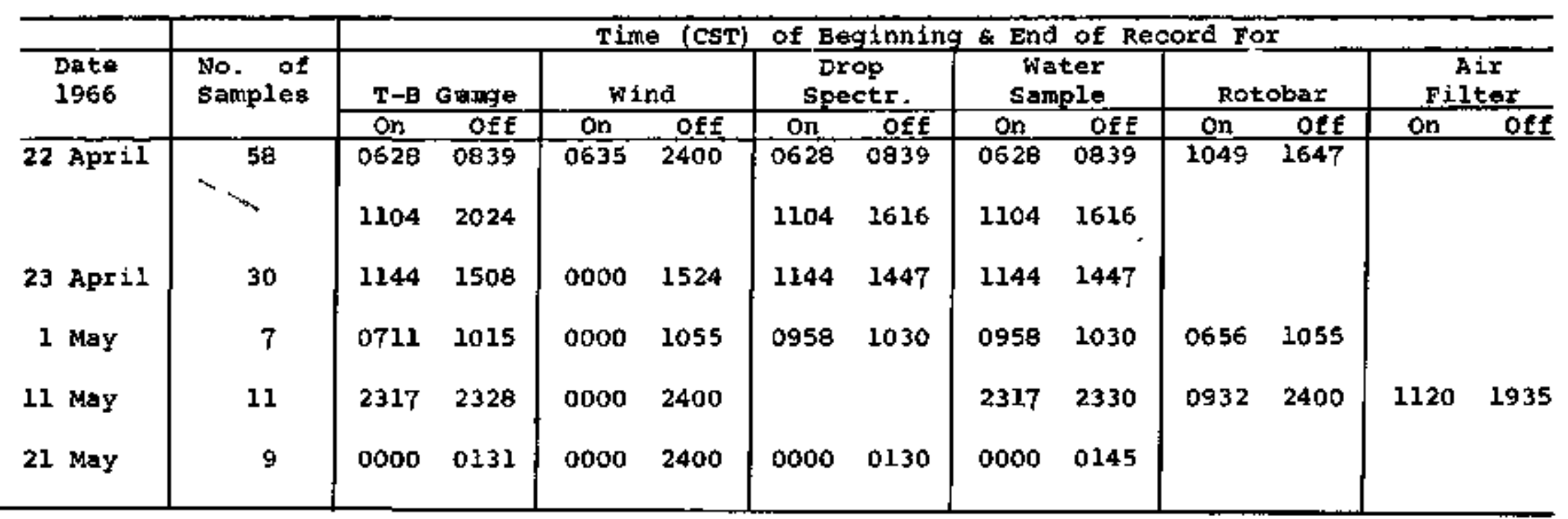


the sampling bottles with glacial acetic acid, zirconium carrier and formalin as a prelininery for our analytical procedures (see Gatz, 1965 ).

An additional special feature of the 1966 field operations was the data recording system that was used for the first tine. By virtue of this systen, which is described below by Dr. V. L. Larrove, we were able to record dropsize and wind direction data on two FM channels, volce coments on an AM channel, and event marks (tipping bucket, wind speed, bottle changes, etc.) and the WW tine sugnal on a second AM channel, all four channels being carried by a 1/4-in. megnetic tape. This development representa a considerable aaving over other tape recording systems having equal capabilities (such as the Ampex 300). We plan to prepare a complete description of the systen for early publication. 


\section{B. DATA RECORDIHG AHD REDUCTION SYSTEMS}

1. The Magnetic Tape Data Recording and Decoding System (V. L. Larrowe) Signals from the raindrop-size spectrometer, as well as supplementary meteorological data such as wind direction, wind velocity, and rate of precipitation are recorded at 7 1/2 inches per second on conventional 1/4-inch magnetic tape. When the tape is played back and the recorded signals are suitably decoded, the resulting outputs may be used directly as inputs to a hybrid (combined analog and digital) computer for any desired type of statistical analysis. Use of the magnetic tape recorder and associated clrcuitry in this manner eliminates the hours of tedious work which would be required if the pulse heights were read directly from a strip-chart recorder by a human operator, and improves the accuracy of the data transferred to the computer.

The bigals are recorded on four separate channels on the $1 / 4$-inch magnetic tape. The tape recorder is a Tandberg Model 64 which was modified as follows:

1. The original erase head was removed and in its position tas mounted a 4-channel Nortronics Type 560 ecord-playback head to permit Bimultaneous recording of 4 data tracks on the tape.

2. The switching, control, input, and output circuits of the recorder were revired to allow B.multaneous recording of two analog FM channels and two direct-record (AM) channels, with capability of continuously monitoring the aignals recorded on the FM channels.

The necessary additional electronics for each FM channel (a voltagecontrolled oscillator for record and an Fu demodulator for reproduce) was provided by an FM recording adapter made by the A. R. Vetter Co, of Iemont, Pa.

The four data tracks on the magnetic tape are, at present, being used as follows. 


\section{Treek H?}

This is the track at the top edge of the tape when the recorder is in a borizontal position. It is used for recording the output signal of the raindrop size spectrometer, and FH analog recording is used so that the signal amplitude from the demodulator wizl nat change with usage or aging of the tape.

\section{Track fte}

The second track down from the top edge of the tape is equipped with direct record (AM) electronics, and is used for volce recording. During field operation of the equipment, when data are being acquired, the operator may vocally record information which will be ueeful in identifying and selecting data to be processed later.

Treck \#3

The third track from the top edge of the tape is connected through FM electronics to record an and log signal from the wind vane representing wind direction.

Track

The last track is used with direct record (AM) electronics to record WWV to provide a time signal, and to record the occurrence of up to 6 sepgrate events.

Each separate event, such as closing contacts on an anemometer, contact closure on a tipping-bucket rain gauge, etc., gates a sigoal into this channel from a separate simusidal oscillator tuned to a distinct frequency. Then, when the tape 1s "played back" later, the sinusoidal signals are separated according to frequency by fllters, and each arives a different relay circuit to produce a contact closure on the relay correbponding to that frequency. Thus, up to 6 different contact closures may be encoded and recorded so that when the tape is" played back, the original sequence of contect closures may be reproduced. 
Assignment of frequencles to the "event" osclilators is as follows:

\begin{tabular}{cc} 
Event No. & Frequency (Hz) \\
\hline 1 & 2000 \\
2 & 3000 \\
3 & 4500 \\
4 & 6750 \\
5 & 10000 \\
6 & 15000
\end{tabular}

a. The Deta Encoding and Recording System

The operation of the data encoding and recording systej will be explained First in terms of the procesaing sequence for each algnal to be recorded.

The most important signal entering this system is that from the raindrop size spectrometer. This is a d-c slepal contalning a sequence or pulses whose amplitudes are proportional to the dianeters of raindrops which are passing through the moving detection volure of the raindrop spectrometer. A diagram representing the handling of this signal in the data encoding and recording system is presented in Figure 1 .

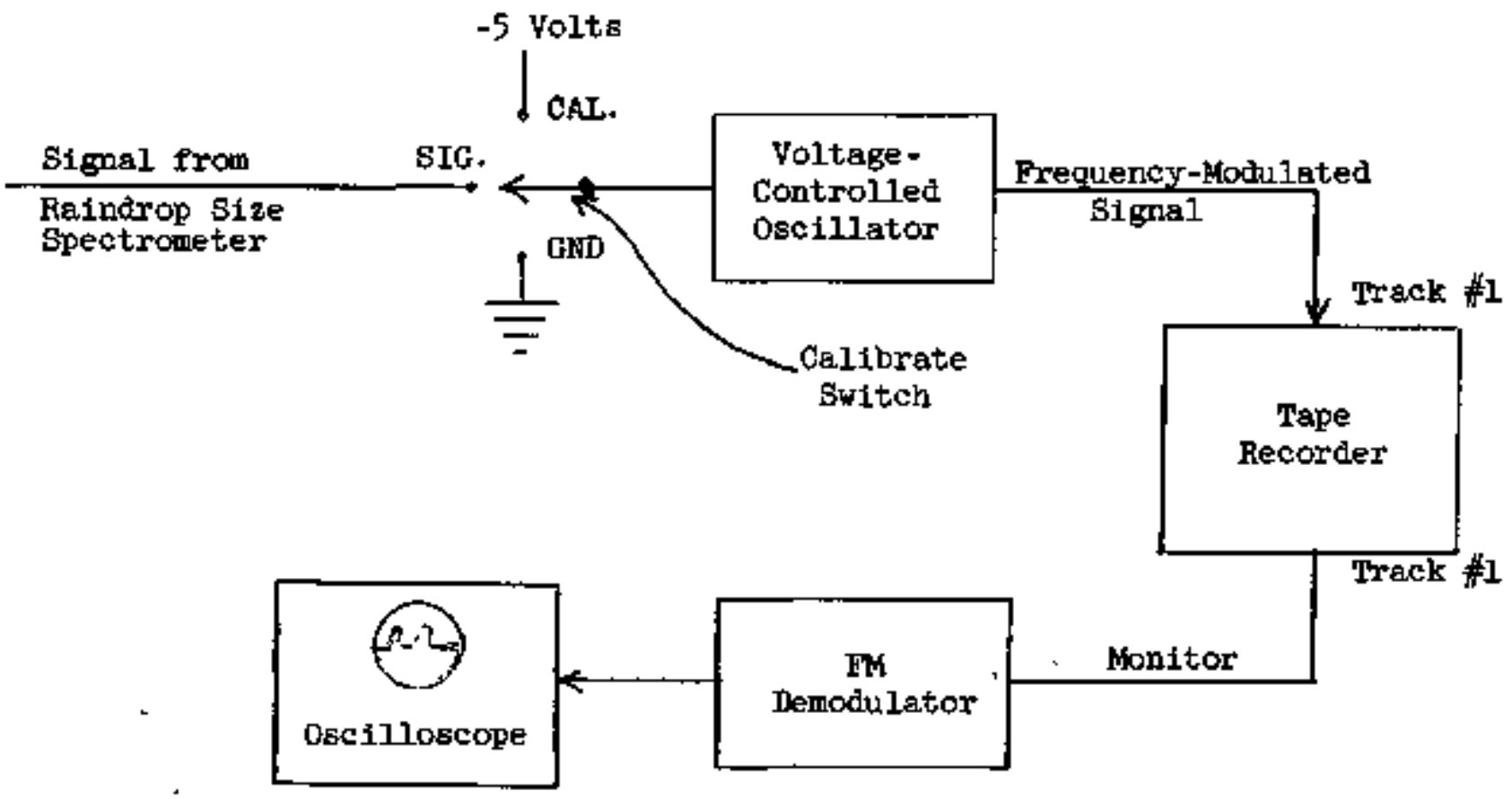

Figure 1. Information flow in channel 1 of the recording system. 
The signal first passes through the "calibrate" swltch. Th1s switch allows the operator to record either the rainorop signal, a signal corresponding to ground (zero volts), or an accurately generated -5 volt $d-c$ signal. The suritch Is normally left on the "signal" position, but it may be rotated mamally to ground or -5 volts to provide a recording of known d-c levels which may be uked as a reference for calibrattng the equipment when the data $1 s$ to be played back and analyzed later.

After passing through the callbrate switch, the sigolal acts on a voltagecontrolled osc1ilator to vary the frequency of an andio frequency 81gnal which this oscillator is producing. The FM output of the voltage-controlled oscillator enters the tape recorder where it is recorded on track \#1 of the magnetic tape.

For monitoring purposes, a separate head in the tape recorder, placed "downstream" from the recording head, is activated by the signal recorded on track \#l. The output of thic playback head is amplified in the tape recorder, and is then passed into the FM demodulator. The FM denodulator produces a signal identical with the original entering the system from the raindrop spectrometer, but displaced in time by the time interral required for any point on the magnetic tape to travel from the recording to the playback head. An oscilloacope may be conpected to the output of the FM demodulator as show to permit direct obseryation of the recorded signal while the recording process is in operation. Another switch in the tape recorder (not shown in Figure 1) permits switching the input of the FM demodulator directly to the output of the veo, thus bypassing the taperecording process in monitoring the signal. This feature is useftul in diagnosing any technical malfunctiona of the equipment, and alao permits monitoring of the raindrop signal when the data are not being recorded.

The data flow diagram for the vind-direction information which is FM recorded on track $\# 3$ of the magnetic tape is similar to Figure 1, the only differences being that, (1) the entering signal is the wind vane signaI, (2) the 
dsta are recorded on track \#3 instead of track \#1, and a d-c voltmeter 1nstead. of an oscilloscope is used for monitoring the output of the FM demodulator.

Track $\#$ of the magnetic tape is used for recording vocal data. The microphone is connected directly into the direet recording electronics for track \#, a system which is built into the tape recorder.

Track is used for recording the National Bureau of standards radio station WWV (for a time reference) and for recording events corresponding to contact closures on the anemometex, ratn gauge, and other apparatus. Each type of event $1 \mathrm{~g}$ represented by a distinct audio frequency tone. A block diagram of the data recording gyster for track f4 is ahow in Figure 2 .

The complete paths for recording Event \#1 and WWV are shown. An osclllator, generating a $2000 \mathrm{~Hz}$ simusoid is in continuous operation. When Event \#1 oceurs, closure of external contacts (on the anemometer in this case) opens the diade gate and causes the $2000 \mathrm{~Hz}$ tone to be passed into the Slgnal M1xer. Also enterIng the Signal Mixer is an audio signal from the Short Wave Recelver, tuned to WWV, the National Bureav of Standards radio station. Other Inputs to the Bignal Mixer, shown entering at the bottom of this block, are signals from 5 other event oscillators and diode gates, each tuned to a different frequency as described previously. The output of the Slgnal Mixer is a signal consisting of a sum of all of the input stgnals, but greatly reduced in amplitude so that the taperecorder input will not be overloaded. This stgnal is direct-recorded on track of the magnetic tape, through electronic circuitry buflt into the tape recorder.

There is no playback head in the tape recorder for tracks the and the record head itself is used for playback when the data reduction process is underway. Hence, it is not possible to monttor the recorded signal on either of these tracks. The Event Decoder and Monitor, which will be described in more detall later, is used for monitoring the combined events signals. This device contains filters, relays, and indicating lights, such that a separate light is actuated for each 


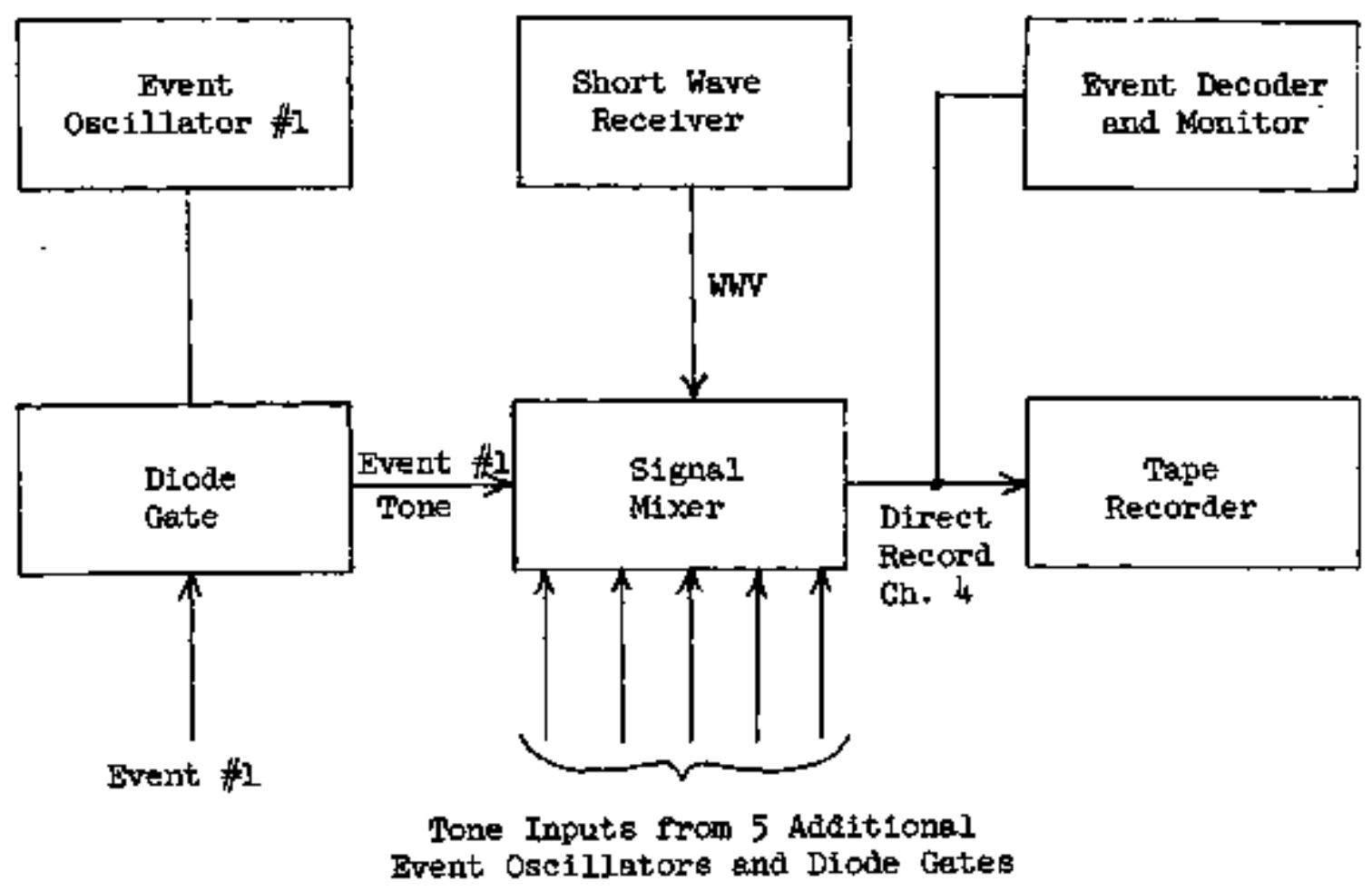

Figure 2. Data recording syaten for track H4 $^{4}$ 
event tone that is present. Thus, visual observation of these lights informs the operator that the event oscillators are being gated and that the correct tone signals are entering the tape recorder.

A block diagram of the complete Data Fncoding and Recording System 18 sbown in Figure 3. Except for the rolee 1ngut to channel 2, of the tepe recorder from the mferophone, all inputs to the systen pasa through the Bvent Bncoder and DC Calibrator at the left center of the diagraid. This unit contains the calibration Bwitch for the DC channels (see flgure 1), the six event oscillators and gates, and the siganl mixer (see Figure 2).

The FM Recording Adapter in Figure 3 containa the two roltege controlled oscillators (VCO's) for generating FM aigrals corresponding to the IC signels from the Raindrop Size spectrometer and the Wind Vane. It alao contains the two Fu Decoders which are used in this set-up for monitoring the recorded aignals. The cutput of the FM decoder correaponding to channel 1 of the recorder ia connected to an oseilloscope for monitoring the raindrop pulses, while the outgut. of the FM decoder associated with channel 3 of the recorder may be connected to a DC voltmeter to permit monitoring the recorded wind-vane signal.

The output of the signal mixer in the Events Encoder block ia directrecorded on track ft of the tape and ia monitored by the Events Decoder and Monitor. 


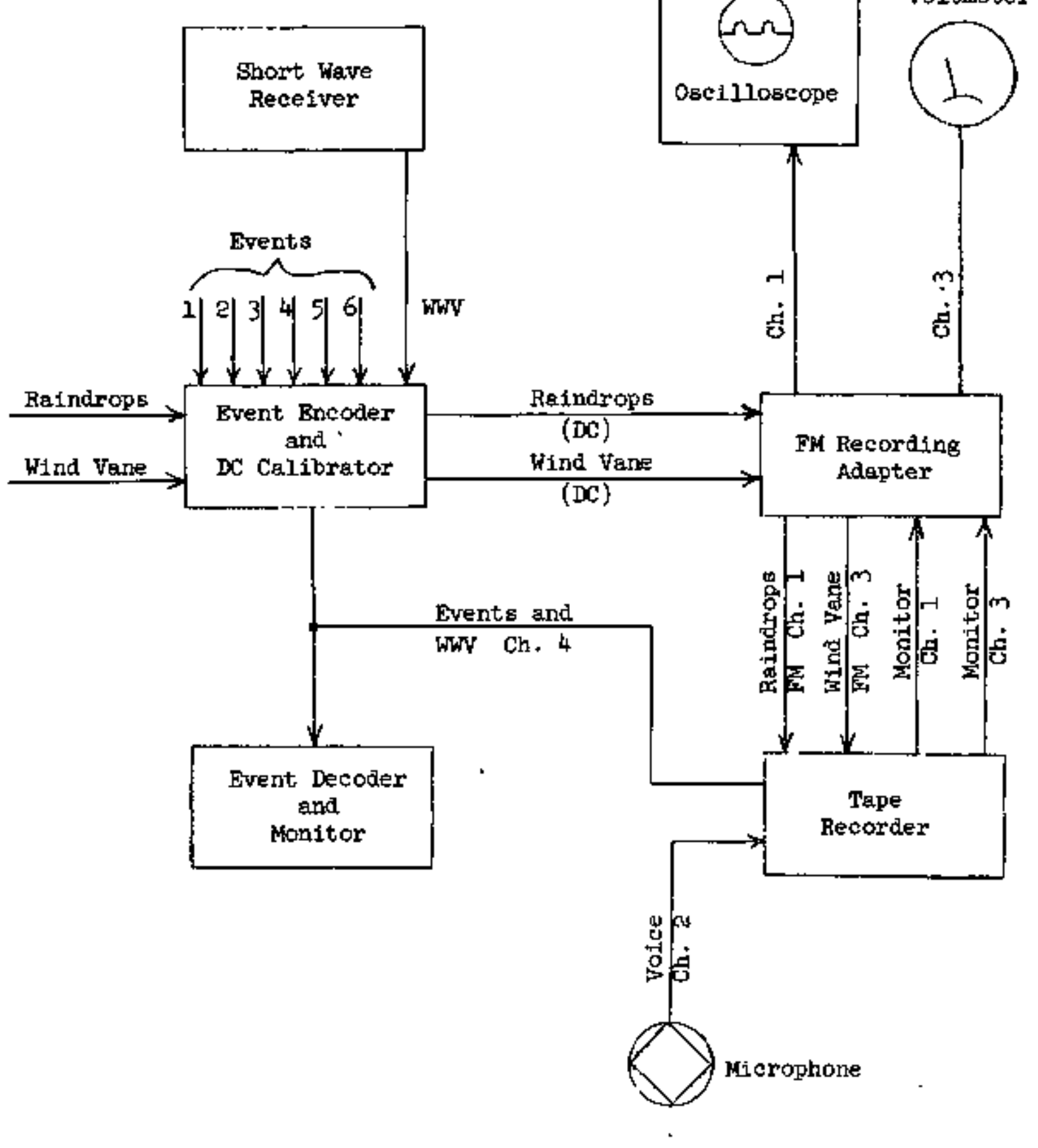

Figure 3. Tata encoding and recording system. 
b. The Data Playback and Decoding System

A block dlagram of the Data Playback and Decoding System is shoun in Figure 4. Here, the FM demodulators in the FM Recording Adapter are again used to demodulate the FM signals on tracks $/ 2$ and $\$ 3$, in exactly the same manner as they were used for monitoring during the recording process. The voltage-controlled oseillators (VCo's) are not used. The output of the track \#t head drives an external ampifier whose output may be connected to earphones or to a loudspeaker, so that vocally-recorded data may be monitored by the operator.

The track $\frac{\pi}{N^{4}}$ head is connected directly to the input of the Event Decoder and Monitor. This device produces a separate relay contact closure for each separate and distinct event tone that is present, and these cixcuits are available for connection into the data-reduction system. Another output of this device is the Event Occurrence Signal, a contact closure that occurs for approximately a 0.2-second time interval whenever any one of the event tones $1 \mathrm{a}$ initiated.

At the present time, the recorded WWV signals may be monitored by the operator through earphones or a loudspeakex connected to the anplifier which is part of the Event Decoder and Monitor. Use of a low-pass Pilter, as shown, will suppress the event tone signals so that the WW signals may be heard more clearly.

A block diagram of the Event Decoder and Monitor is shown in Figure 5 . The signals frow the tape bead for track \#4 are amplified and applied to the inputs of the 6 tone rilters with each filter tuned to the audio frequency indicated on the diagram. The output of each filter is connected to a relay driver. Then any particular tone appears in the amplified signal, it pasges through the filter tuned to its frequency and causes the corresponding relay to be actuated. 


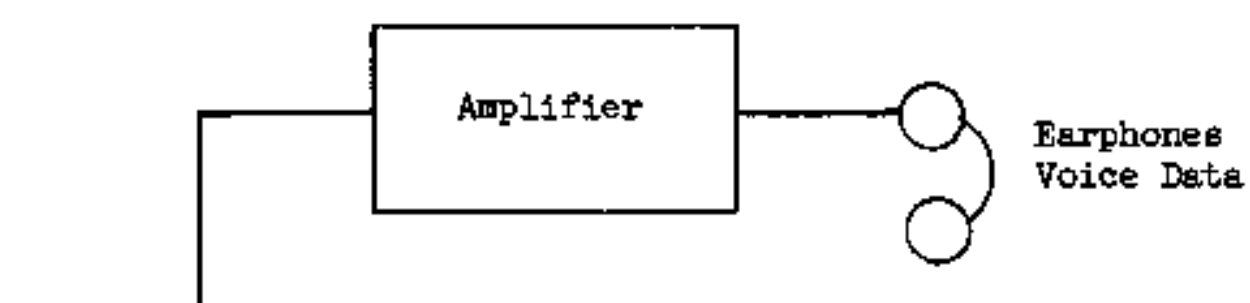

Ch. 2

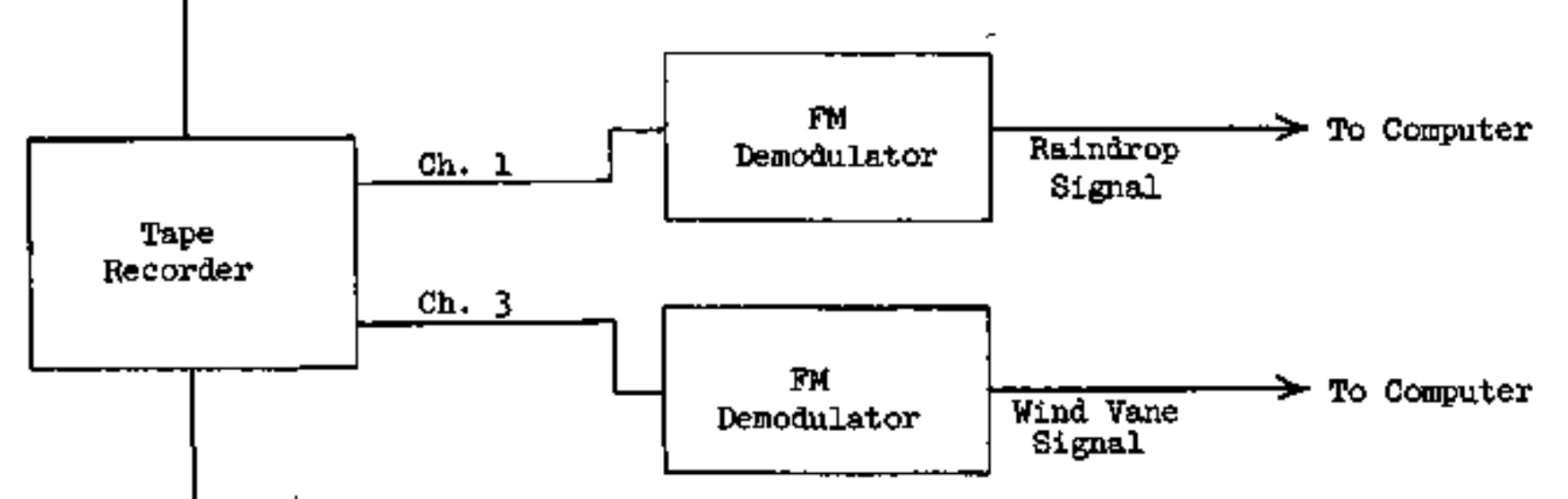

Ch. 4

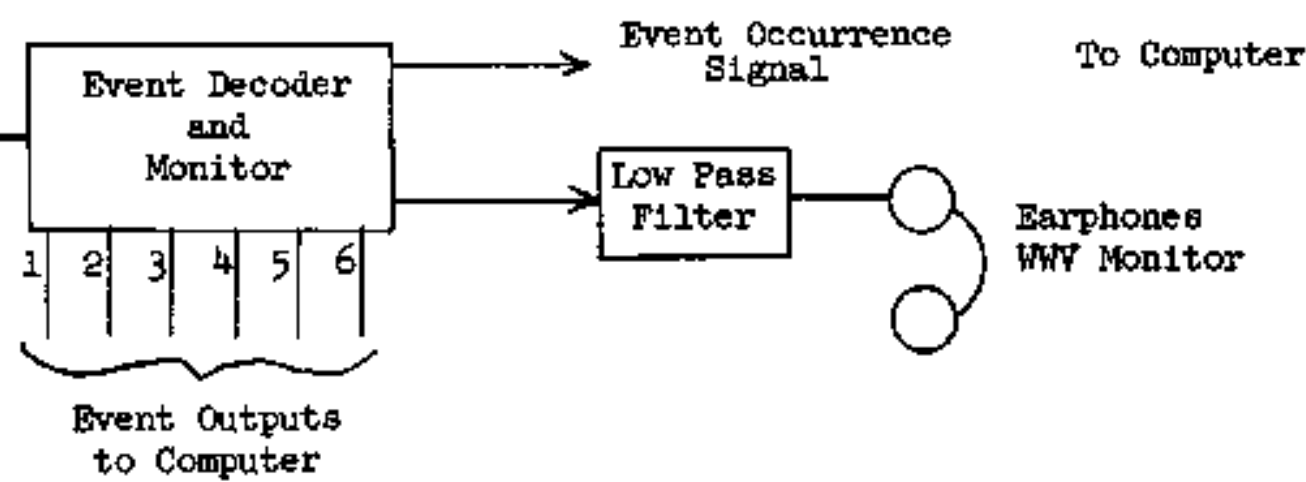

Figure 4. Data playback and decoding system. 

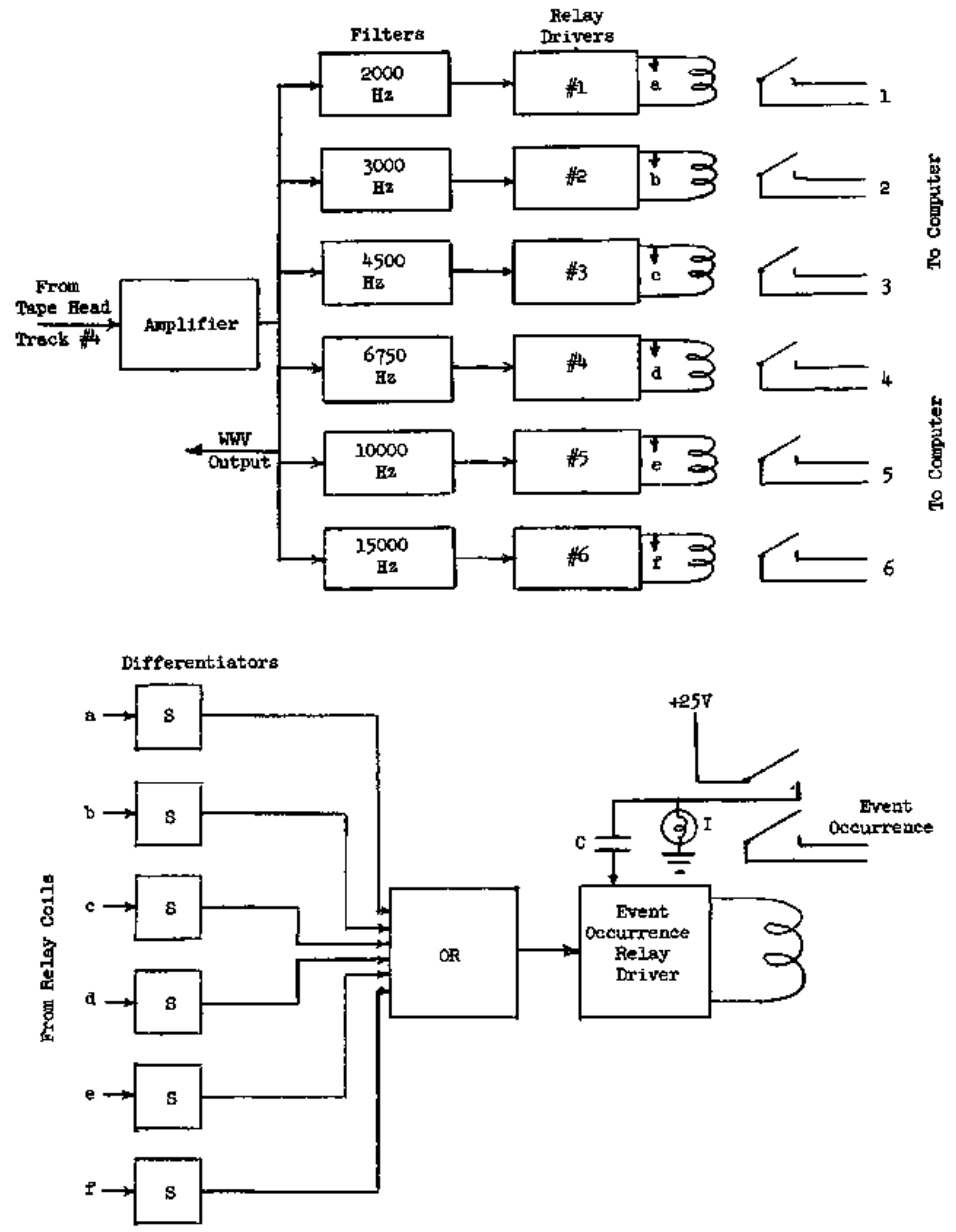

F1gure 5. The event decoder. 
Thenever any event relay is actuated, the voltage on one end of that relay coil drope abruptly from +25 volts to about +5 volts with respect to ground. This end of each relay coil is pessed through en $r-c$ differentiating circuit (marked $s$ on Figure 5) to an input of a diode "OR" gate as shom, so that a negative pulse vill appear at the output of the oR gate every time an event relay is actuated. This negative pulse enters the Event Occurrence Relay Iriver and causes the Event Oecurrence Relay to be actuated. Hormally, the relay would remeid closed only during the brief duration of the pulse from the OR gate. A longer relay closure time is obtained by having a set of relay contacts connect a +25 volt signal through a capacitor $C$ into the relay driver in such a manner that the charging current through the cepacitor causes the driver to continue to actuate the relay. When the capacitor is charged, the signel to the relay driver disappears, and the relay is released. Capacitor C and its asbociated. charging circuit have a time constant of 0.1 to 0.2 second.

\section{Drop Size Deta Reduction (F. V. Brock)}

The magnetic tape containing the trop size data vas processed in the Meteorology and oceanography Computing taboratory (MOCL). The objective was to generate a series of arop size distributions, one for each subset of data on a tape. A subset was defined to be a fixed interyal of time or the interval between the pulses which indicated a bottle change. A magnet1c tape reproducer and FM demodulator were provided to regenerate the data. No spec1al equipment was required.

The procedures used in reducing the data are described in the following paragraphs.

\section{Phage 1}

An analog computer vas used to amplify and bias the pulse signsil from the FM demodulator. A gain of 10 was used to employ effectively the 100-volt range 
of the computer. A bias was used to define an arbitrary base line relative to which all pulse heights were measured. An analog circuit was devised to monitor the signal continualy to compensate for drift with respect to the arbitrary base line.

The resulting pulse signal was digitized at about $5 \mathrm{KHz}$ and a aigital computer monftored the data. The pulse height was defined to be the largest positive value observed before the signal went negative, $i_{*} e_{*}$, below the arbitrary reference level. In this way any ambiguity of multiple drops intone pulse was resolved. The pulse heights were grouped into a 1024-interval distribution table. Each interval waa 0.1 volt wide. With typical system gains (determined by the spectroneter electronics, FM modulator, tape recorder) reproducer, FM demodulator, and the analog computer) a 3.5 un drop was observed as an 80 volt pulse.

Whenever a time algnal (a locally generated time pulse, typically of 5minute period) or an event pulse (indicating bottle change) was observed a new distribution table was started and the old one was written on magnetic tape in binery format.

\section{Fhase $\underline{\underline{2}}$}

The distribution tables were read from the binary tape and rewritten on another tape in BCD format. This allowed subsequent processing either in the NocL or at the Univeralty Computing Center. Optionally, plots of the raw distributions could be obtained during this phase.

\section{Fhase 3}

The objective of this, as yet uncompleted phase, is to locete the distribution tables which contaln the sequence of calibration pulses and determine the amplitude of those pulses. Using the four drop sizes in the calibration gequence the distribution tables can be corrected from volts to millimeters of drop diameter and then regrouped into the final distribution. The advantage of this approach is that the drop stzes can be accurately determined independent of system gain which has been observed to vary conaiderably from tape to tape. Since the original distributions were obtained with high resolution they can be regrouped readily into the much cosrser final distribution.

The accuracy of this data reduction procedure is determined by the sample rate and the frequency components present in the pulses including noise. For a fixed sample rate, the accuracy will diminish as the high frequency content of the pulse waveform increases. The probability of sampling the pesk value of a pulse diainishes as the pulse waveform becomes more peaked. In this situation the apparent pulse height is less than the tone polse height. Since peak values are being read, noise added to the basic pulse has the effect of increasing the apparent pulse height, so that these two effects tend 
to compensate. The procedure was tested using sine vares of several amplitudes and frequencies. For sine waves of 10 - to 100 -volt amplitude and up to $300 \mathrm{~Hz}$ the reported average amplitude was accurate to uithin 0.2 volt but the accuracy deteriorated rapidly at h1gher frequencies and high amplitudes. A 100-rolt sine wave at $400 \mathrm{~Hz}$ showed a 1 volt error. It was estimated that the frequency content of the drop pulses was usually much lower than $400 \mathrm{~Hz}$. However even a 1 volt or 1 percent error would not be very signifigant in the final drop size distribution since the class size width is 0.2 min which is usuelly about 4.5 volts. Th. is pertinent also to emphasize that this relatively large error, in sbsolute terms, applies only to the extreme tail of the drop-size distribution. Hence its total impact is very small indeed.

\section{Autowatic Reduction and Tabulation of Other Data Componenta}

As is evident in the material presented above, we have this year mored from our former position of using relatively simple analog and event-merking records reduced manually to digitel form to one of using a more sophisticated deta-recording and -reducing system. We anticipete two major gains form this move: (a) the elimination of the inevitable human error or the former system, and (b) the earlier avallability of our data in tabular form. The second of these gaina, however, is not oura until the syatem has been completely worked out and tested.

Of the many possibilities open to us, we have chosen to treat the data basically as research information, rather than as information the content of which may be severely reduced. The procedure which we are working on will therefore first reduce the anslog and event records to a sequential digital form which will contain all the original information within acceptable error limits. The resulting digital tape will be compatible with our digital computer focilities and will be avallable as data input for the various computational programs that will be devised to meet specific research needs.

It is anticipated that this syatem will be completed and tested during the aumer, 1967.

C. RESULTS

1. Rainfall and Sample Date

The data log has been presented in Table $I$. The semples are individually identified with sample mean rainfall rates in Table II. One hundred and four samples were collected in all. Most of these were taken within mesningful aequences, but a few in isolated light showers were considered inadequate and irrelevant to our objectives. 


\section{Radioactivity Analysis}

Beta-counts were made for the samples, as for previous experiments, by the National Sanitation Foundation. The total B-radioactivity for each sample is given in Table II and the several sequences of $\beta$-concentrations are plotted in Figure 6. The 100-fold increase from late April and early May to 21 May is attributed to the contribution of the third chinese nuclear test of 9 May 1966.

\section{Deuterium and Tritium Analyses}

Analysea for deuterium, D, and tritíum, T, were done by Dr. Dieter $H$. Ehhalt of NCAR. These have been done on alternate samples of the series supplied to Dr. Ehhalt, and the results obtained to date are given in Table II. Tritium amounts are reported in tritiun units (T.U.):

$$
1 \mathrm{TU}=1 \mathrm{~T} \text { atom } / 10^{1 \mathrm{~B}} \text { atoms } \mathrm{H}
$$

Deuterium amounts are expressed in terms of the relative deviation, 8 , from standard mean ocean water (SMOW) as deflined by Craig (1961):

$$
8 \%=\left(\frac{\mathrm{R}_{\mathrm{sa}}}{\mathrm{R}_{\mathrm{smow}}}-1\right) \cdot 10^{3}
$$

where $\mathrm{R}$ is the isotopic ratio of deuterfum to hydrogen:

$$
R=\frac{[\mathrm{D}]}{[\mathrm{H}]}
$$

and the subscripts sa and smow designate, respectively, the sample and standard mean ocean water.

The analyses for deuterium are not yet completed.

Initial superficial study of the tritium trends indicate the following:

(a) The expected springtime increase of $T$ :

(b) a slight negative correlation of $T$ with the rainfall rate in the 22 April rain, which fa similar to the regult reported by Bleeker, Dansgaard, and Lablans (1966); and

(c) a relatively steady Increase of $T$ with time during the 23 April rain.

Inasmuch ess the $\beta$-counts show a great jump between 11 kay and 21 iky, 


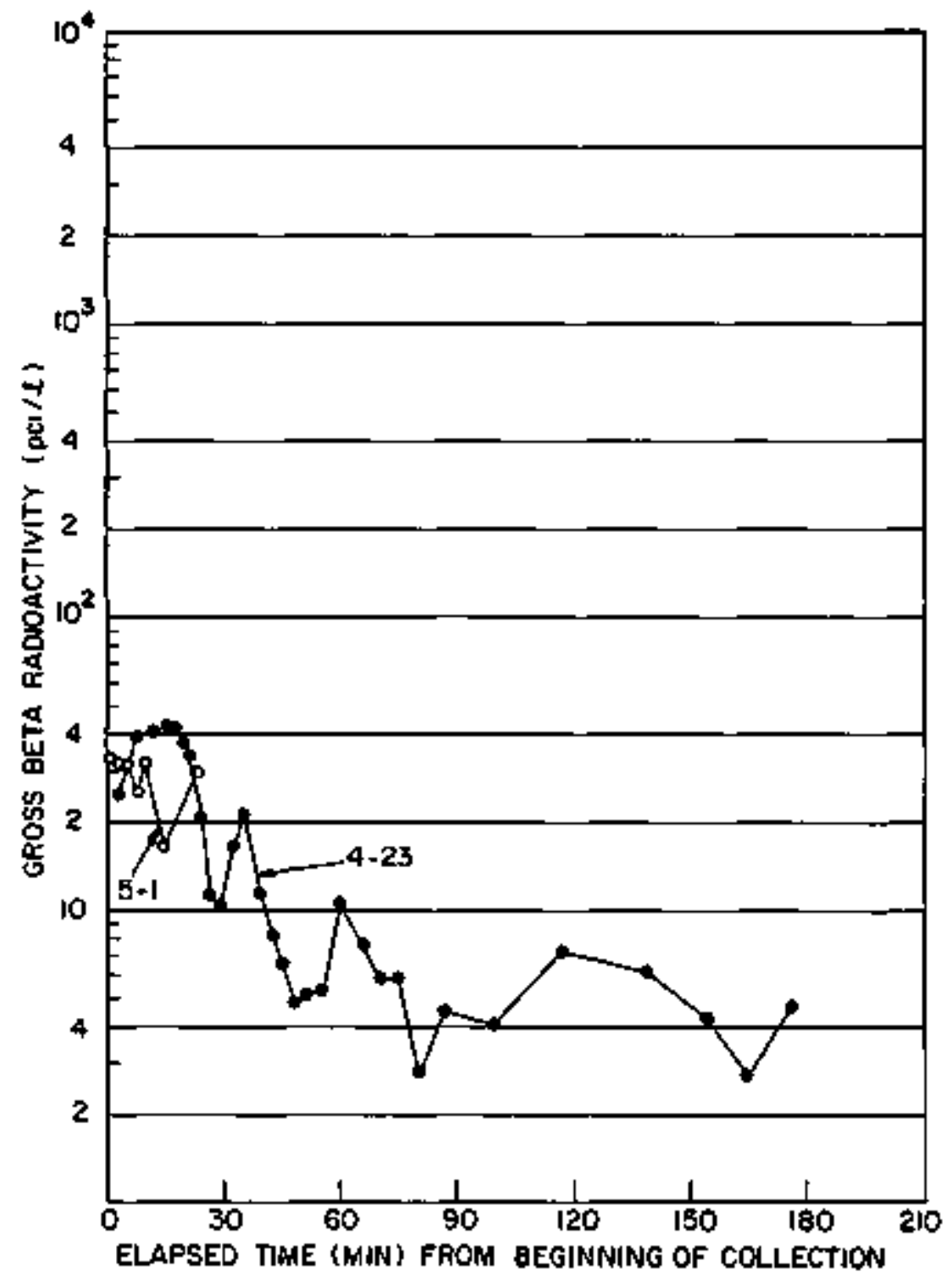

Flgure 6. Groga Beta-Radoactivity Curves for Raln amples taken in AprilHey, 1966. 


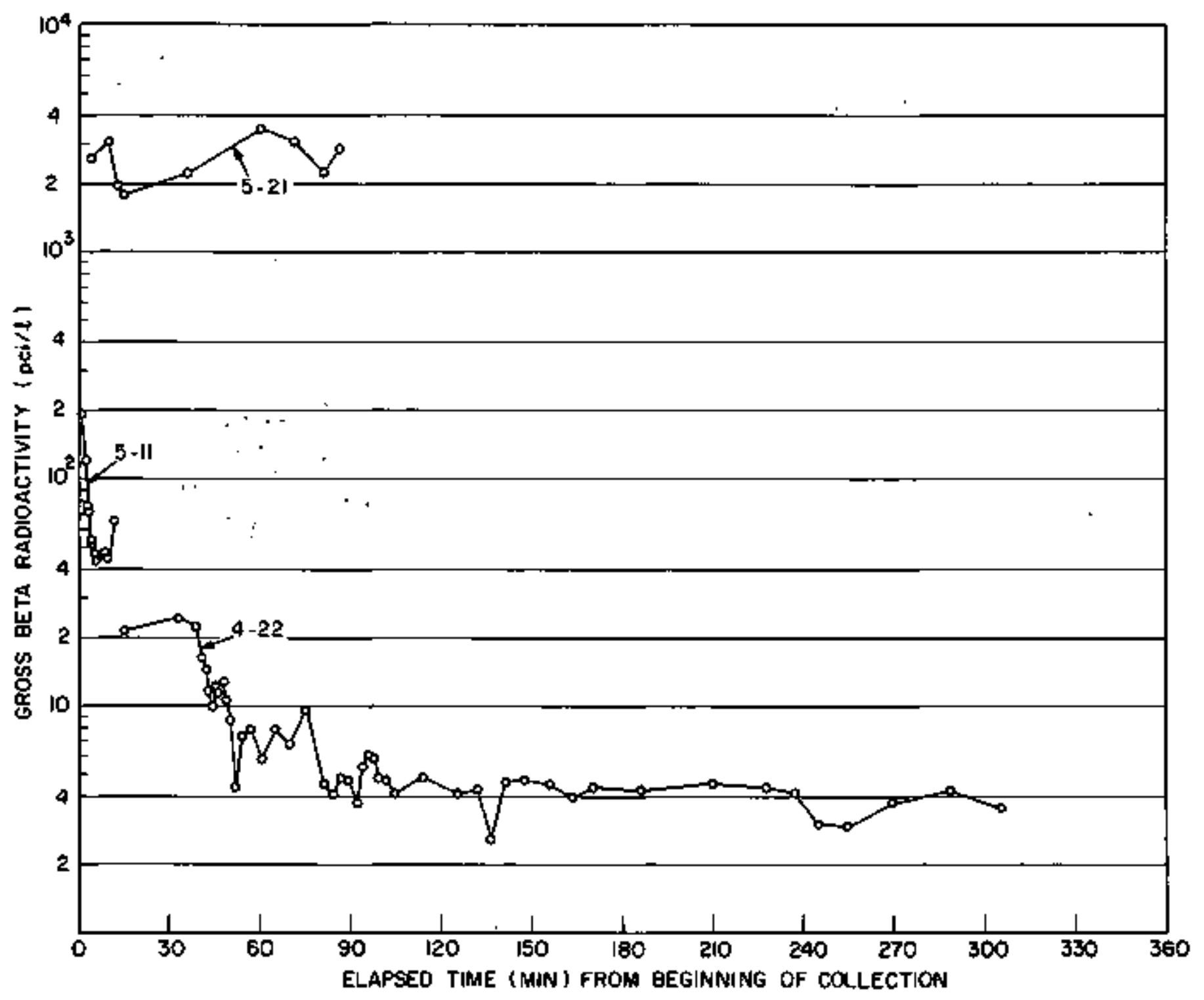

Figure 6. Concluded. 
TAHLE II

FOSSIITS OF AMALYSES FOA BETA-RADIOACTIYITY, TRITIIM, AND DEUTERIDM

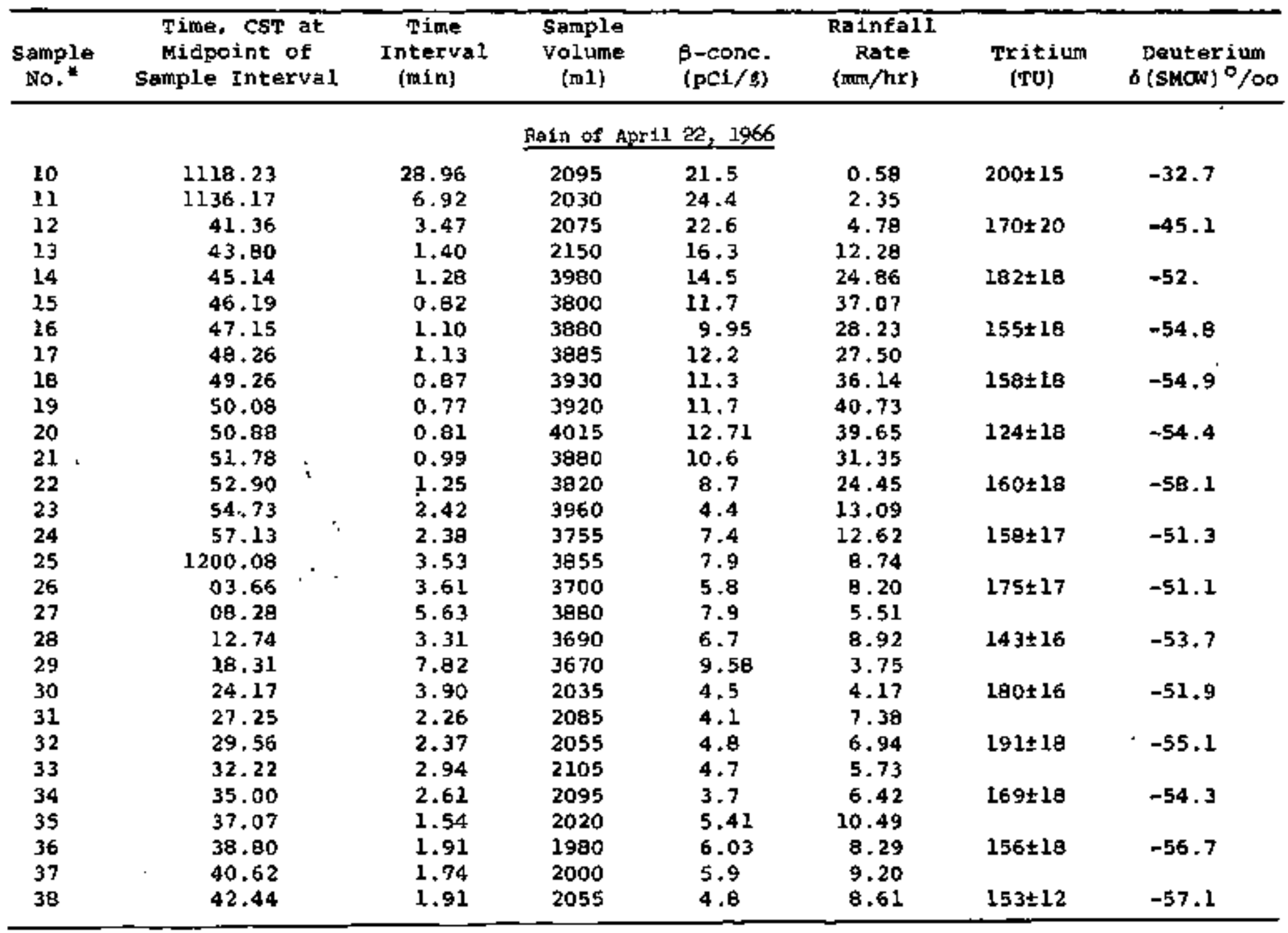

"The first nine sampleg were obtalned ia relatively brief shoters, and have been diverted for use 1a tegting our neutron activation procedures. 
TABLE II (Contanued)

\begin{tabular}{|c|c|c|c|c|c|c|c|}
\hline $\begin{array}{c}\text { Sample } \\
\text { No.* }\end{array}$ & $\begin{array}{l}\text { Time, csT at } \\
\text { Mldpoint of } \\
\text { Sample Interval }\end{array}$ & $\begin{array}{c}\text { Trme } \\
\text { Interval } \\
\text { (min) }\end{array}$ & $\begin{array}{l}\text { Sample } \\
\text { volume } \\
\text { (ml) }\end{array}$ & $\begin{array}{c}\beta-\operatorname{conc} . \\
(\operatorname{pco} / p)\end{array}$ & $\begin{array}{c}\text { Rainfali } \\
\text { Rate } \\
\text { (moro } / h r)\end{array}$ & $\begin{array}{l}\text { Tritium } \\
\text { (TU) }\end{array}$ & $\begin{array}{c}\text { Deuterium } \\
\delta \text { (smow })^{\circ} / 00\end{array}$ \\
\hline \multicolumn{8}{|c|}{ Razn of April 23, 1966 (coneluded) } \\
\hline $\begin{array}{l}67 \\
68\end{array}$ & $\begin{array}{l}10.36 \\
12.97\end{array}$ & $\begin{array}{l}2.07 \\
3.16\end{array}$ & $\begin{array}{l}1962 \\
1985\end{array}$ & $\begin{array}{l}11.2 \\
10.3\end{array}$ & $\begin{array}{l}7.58 \\
5.02\end{array}$ & & \\
\hline 69 & 15.56 & 2.03 & 2110 & 16.6 & B. 32 & & \\
\hline 70 & 18.63 & 4.10 & 4100 & 21.2 & 8.00 & $173 \pm 10$ & \\
\hline 71 & 22.72 & 4.08 & 3700 & 11.4 & 7.25 & & \\
\hline 72 & 26.30 & 3.07 & 3680 & 8. 24 & 9.59 & & \\
\hline 73 & 29.24 & 2.02 & 3770 & 6.6 & $10+70$ & & \\
\hline 74 & 32,16 & 3.02 & 3920 & 4.81 & 10.38 & $174 \pm 16$ & \\
\hline 75 & $35+10$ & 2.85 & 3790 & 5.10 & 10.64 & & \\
\hline 76 & 39.03 & 5.02 & 3750 & 5.33 & 8.96 & & \\
\hline 77 & 44,13 & 5.16 & 3620 & 10.5 & 8.39 & & \\
\hline 78 & 49.38 & 5.32 & 3790 & 7.56 & 8.55 & $205 \pm 19$ & \\
\hline 79 & 54.24 & 4.40 & 3955 & S.96 & 10.77 & & \\
\hline 80 & $5 \theta+46$ & 4.03 & 3770 & $\$ .98$ & 11.22 & & \\
\hline 81 & $1303.46^{4}$ & 5.98 & 3630 & 2.80 & 7.28 & & \\
\hline 82 & 10.66 & B. 42 & 4035 & 4.53 & 5.75 & $189 \pm 18$ & \\
\hline 83 & 22.71 & 15.68 & 6820 & 4.08 & 5.22 & & \\
\hline 84 & 40.86 & 20.61 & 7625 & $7 . \$ 1$ & 4.44 & & \\
\hline 85 & 1402.08 & 21.84 & 7670 & 6.22 & 4.21 & & \\
\hline 86 & 17.68 & 9.75 & 7220 & 4.31 & 8. B9 & $249 \pm 16$ & \\
\hline 87 & 28.09 & 20.68 & 7300 & 2.73 & 8.20 & & \\
\hline 88 & 40.10 & $13+34$ & 7320 & 4.76 & 6.58 & & \\
\hline \multicolumn{8}{|c|}{ Rain of May 1, 1966} \\
\hline 92 & 0958.95 & 1.57 & 2085 & 33.2 & 10.62 & & \\
\hline 93 & 1001.05 & 2.64 & 2056 & 32.2 & 6.23 & $550 \pm 22$ & . \\
\hline 94 & 03.69 & 2.64 & 2040 & 31.9 & 6.18 & & \\
\hline 95 & 06.06 & 2.11 & 2008 & 25.3 & 7.61 & $540 \pm 22$ & \\
\hline
\end{tabular}

* Fanples $89,90,91$ were obtained 1 in brief 1ntermittent showers on April 28,39 , and 30 . 
TABLE $\amalg$ (Continued)

\begin{tabular}{|c|c|c|c|c|c|c|c|}
\hline $\begin{array}{l}\text { Sample } \\
\text { No. }\end{array}$ & $\begin{array}{c}\text { Time, CST at } \\
\text { Midpoint of } \\
\text { Sample Interval }\end{array}$ & $\begin{array}{c}\text { Time } \\
\text { Interval } \\
\text { (min) }\end{array}$ & $\begin{array}{c}\text { Sample } \\
\text { volume } \\
\text { (ml) }\end{array}$ & $\begin{array}{l}\rho-\operatorname{conc} \text {. } \\
(\mathrm{pcs} / \mathrm{R})\end{array}$ & $\begin{array}{c}\text { Rainfall } \\
\text { Rate } \\
\text { (mm/hr) }\end{array}$ & $\begin{array}{l}\text { Tritium } \\
\text { (TU) }\end{array}$ & $\begin{array}{l}\text { Deutezium } \\
\delta \text { (SMON) } \% / 00\end{array}$ \\
\hline \multicolumn{8}{|c|}{ Ra1n of April ez, 1966 (concluded) } \\
\hline $\begin{array}{l}39 \\
40 \\
41\end{array}$ & $\begin{array}{r}44.56 \\
47.55 \\
56.74\end{array}$ & $\begin{array}{r}2.32 \\
3.66 \\
14.72\end{array}$ & $\begin{array}{l}1875 \\
1950 \\
3850\end{array}$ & $\begin{array}{l}4.7 \\
4.1 \\
4.85\end{array}$ & $\begin{array}{l}6.46 \\
4.26 \\
2.09\end{array}$ & $158 \pm 18$ & -55.5 \\
\hline 42 & $1308+40$ & 8.59 & 3760 & 4.1 & 3.50 & $160 \pm 19$ & -54.6 \\
\hline 43 & 15.08 & 4.78 & 3780 & 4.3 & 6.33 & & \\
\hline 44 & 19.46 & 3.97 & 3720 & 2.6 & 7.50 & $206 \pm 19$ & -59.2 \\
\hline 45 & 24.08 & 5.29 & 3760 & 4.63 & 5.70 & & \\
\hline 46 & 30.08 & 6.72 & 3845 & 4.72 & 4.58 & $138 \pm 18$ & -57.5 \\
\hline 47. & 38.32 & 9.77 & 3670 & 4.5 & 3.00 & & \\
\hline 48 & 46.32 & 6.23 & 4045 & 4.0 & 5.19 & $153 \pm 18$ & \\
\hline 49 & 52.74 & 6.61 & 3798 & 4.4 & 4.60 & & \\
\hline so & 1408.92 & 25.73 & 7070 & 4.27 & 2.20 & $177 \pm 17$ & \\
\hline 51 & 32.88 & 22.19 & 7375 & 4.59 & 2.66 & & \\
\hline 52 & 50.79 & 33.64 & 7150 & 4.38 & 4.19 & $141 \pm 18$ & \\
\hline 53 & 1500.91 & 6.60 & 6960 & 4.11 & B.44 & & \\
\hline 54 & 07.97 & 7.52 & 7405 & 3.03 & 7,80 & $122 \pm 30$ & \\
\hline 55 & 17.98 & 12.50 & 6850 & 2.95 & 4.38 & & \\
\hline 56 & 33.30 & $18+15$ & 7250 & 3.73 & 3.20 & $163 \pm 18$ & \\
\hline 57 & 52.44 & 20.11 & 7050 & 4.22 & 2.80 & & \\
\hline 58 & 1609.28 & 13.59 & 7700 & 3.52 & 4.53 & $167 \pm 17$ & \\
\hline \multicolumn{8}{|c|}{ Ra1n of Apr:1 23, 1966} \\
\hline 59 & 1146.56 & 6.05 & 2010 & 24.9 & 2.66 & & \\
\hline 60 & 51.22 & 3.25 & 1920 & 39.0 & 4.73 & & \\
\hline 61 & 55.20 & 4.73 & 2010 & 41.1 & 3.40 & & \\
\hline 62 & 58.70 & 2.26 & 2005 & 42.6 & 7.10 & $127 \pm 18$ & \\
\hline 63 & 1200.72 & 1.77 & 1968 & 42.2 & 8.90 & & \\
\hline 64 & 02.74 & 2.27 & 1988 & 36.9 & 7.00 & & \\
\hline 65 & 05.12 & 2.49 & 2000 & 33.9 & 6.42 & & \\
\hline 66 & 07.84 & 2.96 & 1955 & 20.8 & 5.28 & $152 \pm 18$ & \\
\hline
\end{tabular}


TAELE II (Concliaded)

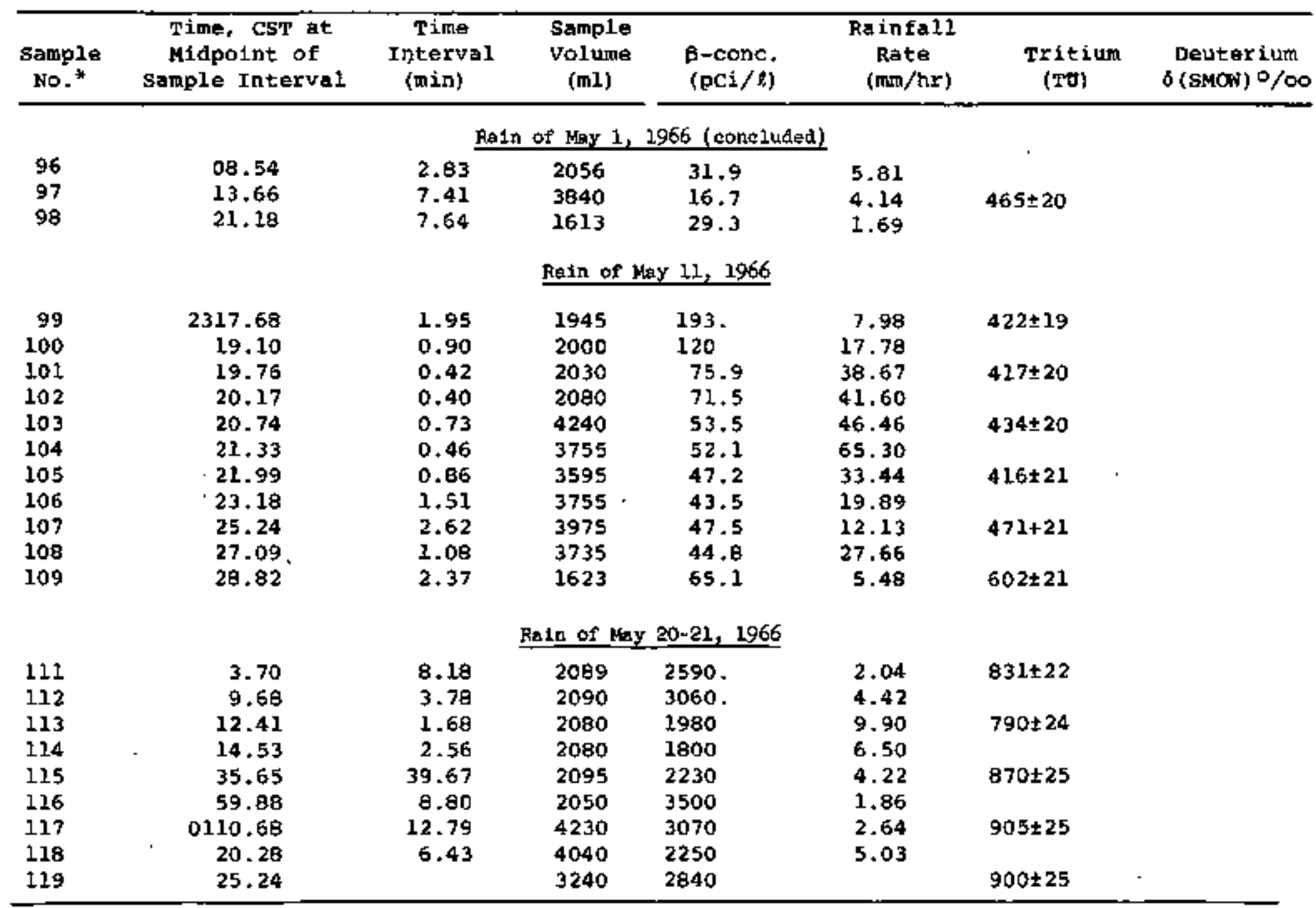

* Semple 110 tas a fragmentary sample, the beginning time of which was not recorded. 
which we attribute to the Chinese test, a coordinated study of the tritium and deuteriun results as soon as they are available appears to hold promise of interesting findings. Relevance to the processes of particulate versus gaseous scavenging should not be overlooked. The relation of the $D$ concentrations to the extent of evaporation from the falling rain (Ehhalt, et al., 1963) is also of interest in connection with our independent evaluations of evaporation based upon drop size data, and of the water budgets of these raingenerating aystens.

4. Pollen Anazysis

The samples vere processed as before for pollen-counting as a separate and coordinated measure of the scevenging effect of rain. We have only recently been able to retain a qualified pollen analyst, 50 as yet these data are not avallable, but they will be forthcoming. 


\section{TRACER STUDY}

The idea of introducing controlled tracers as a logieal development from our line of research wth uncontrolled tracers was conceived prior to our fleld progran of 1966. It was not activated during that progran because of several factors, but the planning to introduce controlled tracer experiments into our field work has proceeded.

In broad terms, we envision two main objectives of such experiments: (1) to isolate the scavenging mechanisms of nucleation, diffusion, and impaction from one another by selecting tracers having appropriate particle size ranges and chemical properties, and (2) to test some of the basic hypotheses about circulations in aevere storms, such as oura (IIngle and Gatz, 1966) pertaining to the main iumediate atmospheric sources for the contaninants collected by rein, and Browning ${ }^{+} s$ (1964) regarding the pregence of a middle-level (near $6 \mathrm{~km}$ ) indraft feeding the jor downdraft of the highly organized sR (severe, right-turning) storms.

\section{A. CHOICE OF TRACER MATERTAL}

The development of silver iodide as a cloud seeding agent figured prominently in the infial design of our pilot experlments. Because of its history, the means for dispensing AgI from an aircraft in finely divided form were already avaliable. To field a pilot experiment it wes necessary to avoid developmental problems as much as possible. It elso early appeared necessary to dispense our tracer froil a small aircraft. Syatems available for this $\mathrm{k}$ ind of operation with silver iodide are (1) an acetone solution burner developed by the U.S. Forest Service, and (2) pyrotechnic flares developed by the U.S. Navy.

Considerations such as the use of I-131 labeled silver lodide, with neutron activation measurement of the silver component, entered our early discassions, but health and ssfety considerations militated against the use of any radioactive species, and finally against ary known cloud-seeding material. The latter point becornes clearer when one notes that our operation is aet in Oklahoms at the height of the tornado season. Since it is not clear what effect AgI might have upon a severe storm, it must be considered unsafe to introduce it into such storms because of its ice-nucleation properties, and the risk may be completely out of proportion to any real effect produced by AgI.

Thus ner criterta entered the discussion, and the necessity for basic development beceme evident. We settled upon neutron activation as the basic evaluation technique, and then chose a tracer idealized for measurement by this technique: indium. Table III gives date on In and Ag to show their relative merits for neutron activation measurement. In addition to the pro* 
perties enumerated here, In exhibits chemical behavior thet causes it to be

TABLE III

NEUTRON ACTIVATIOH DATA FOR INDIUM AND SILVER

\begin{tabular}{|c|c|c|c|}
\hline \multirow{3}{*}{$\begin{array}{l}\text { Stable 1sotope: } \\
\text { Abundance: } \\
\text { Thermal neutron }\end{array}$} & \multirow{3}{*}{$\begin{array}{l}\text { Indium } \\
115 \\
95.72 \%\end{array}$} & \multicolumn{2}{|c|}{ Silver } \\
\hline & & 107 & 109 \\
\hline & & $51.82 \%$ & $48.18 \%$ \\
\hline cross-section: & 154 barns* & 40 barns & 82 berns \\
\hline letivated isotope: & $116 \mathrm{~m}$ & $108 \mathrm{~m}$ & $110 \mathrm{Bg}$ \\
\hline Half-life: & $54 \mathrm{~min}$ & $2.4 \mathrm{~min}$ & 249 days \\
\hline
\end{tabular}

*Ir-115 has a resonance absorption cross-section of about 10,000 barns at $1.4 \mathrm{ev}$.

favored over Ag because the analytical procedures are simpler for In.

\section{B. DEVELOFMENT OF TRACER ENIISSION}

The melting point of $\mathrm{InCl}_{3}$ is $596^{\circ} \mathrm{C}$, and $1 \mathrm{t}$ sublines at temperatures below $400^{\circ} \mathrm{C}$, and volatilizes at $600^{\circ} \mathrm{C}$. Accordingly, emission in vapor form by either of the techniques used for the aircraft emission of AgI appears feasible. Other chemical properties lead one to expect that $\mathrm{InCl}_{3}$ can be mixed into a pyrotechnic formulation in a manner analogous to that used in making. AgI cloud-seeding flares (Finnegan, et al., 1967). An approsch to olin Associated Products operations was dade, and the development of the appropriate pyrotechnic mixture, and manufacture of the flares was erranged.

\section{DEVESOREFTI OF ANALYSIS PROCEDURE}

We were informed by C. M. Gordon* of the U.S. Naval Research Laboratory that indiun can be conventently measured by neutron activation technique in quantities as small as $10^{-10} \mathrm{gm}$. To do this, however, requires a sound procedure, and to launch field experiments requires that the analytical procedure and the mounts of tracer emitted be reasonably compatible. The following procedure was developed by Dr. Donald F. Gatz and Professor J. $W$. Winchester

*Private comurunication dated 16 February 1967, transuitting copy of manuscript to be offerred for early publication. 
of our staff working in close collaboration.

Frincipal features of the chemical procedure are the scatenging of indium frow solution by the precipitation of ferric hydroxide, and the use of stable lanthanum as an internal standard. A basic precaution of maintaining an ac1d solution prior to processing is observed to avoid the adsorption of indium onto the container walls. Accordingly the sample collectore are primed using $50 \mathrm{ml}$ of $6 \mathrm{~N} \mathrm{HCl}, 5 \mathrm{mg}$ of $\mathrm{Fe}$, and $\mathrm{k \mu} \mathrm{gm}$ of La-t39 for each $1000 \mathrm{ml}$ of sample rain water. Frior to the first chemical precipitation, the sample, treated as above, is rough-filtered to eliminate particles of order lou radius and larger. Chemlcal precipitation $1 \mathrm{~s}$ done by adding $50 \mathrm{ml}$ of $7.5 \mathrm{~N} \mathrm{NH} / \mathrm{OH} / 1000 \mathrm{ml}$ of sample. This produces $\mathrm{Fe}(\mathrm{OH})_{3}$ which precipitates out scavenging $\mathrm{In}^{+++}$ quantitatively, and the precipitate is collected by filtration using a membrane filter (pore size $0.45 \mathrm{H}$ ). The membrane filter is iminediately placed in a capsule for subsequent neutron activation.

Activation will be done in the Ford Reactor of The University of Milchigan Menorial-Phoenix Foundation. The procedure calls for irradiation for 10 to 20 min in a flux of $2 \times 10^{12}$ neutrons $\mathrm{em}^{-2} \mathrm{sec}^{-1}$. This is followed by a radiochemical separation of the resulting la-140 standard from the In-116m sample prior to counting. The separation requires that the $\mathrm{Fe}(\mathrm{OH})$ z precipitate be dissolved again by leaching the membrane filter with $6 \mathrm{~N}$ HCi. This acid solution is again precipitated as before by adding $\mathrm{NH}_{4} \mathrm{OH}$, but is this time collected on a fritted glass filter. It 18 then dissolved again, this time using $6 \mathrm{~N} \mathrm{HBr}$ from which solution the In-116 m is extracted into isopropyl alcohol by adding the alcohol and shaking. This procedure leaves the La-140 in aquepus phase whereas the $I n-116 \mathrm{~m}$ goes into the organic phase. At this point the aqueous fraction is separated from the organic. The La-140 is then prectpitated with $\mathrm{Fe}(\mathrm{OH})_{3}$ again and counted; the In-116 In mist be backextracted from the isopropyl alcohol using dibtilled water, when it too can be precipitated with $\mathrm{Fe}(\mathrm{OH})_{3}$ and counted.

Simple B-counting is used finglly in preference to $\gamma$-analysis because of its greater sensitivity.

In developing the procedure, $\gamma$-ray analysis was used in addition to the $\beta$-counting as a check on the purity of the La- 140 and $I n-116 \mathrm{~m}$. The procedure, as tried on local samples of rain and snow, appears easily capable of measuring $5 \times 10^{-10}$ gw of In within 10\%. It is anticipated that this procedure will be written up for publication by Professor Winchester and Dr. Gatz.

\section{EXPERTMENTAL DESIGN}

The initial pilot experiments are delineated by a combination of physical objectives and by expediency. The latter is expressed in the minimization of developmontal taske and the utilization of available techniques. This com- 
ponent, for example, has been a major factor in the decision to.test first for the purely diffusite attachment of tracer to larger airborne particles prior to deposition. This decision is supported by the avaslability of the pyrotechnic flare dispensing technique and of the aircraft equipped for this kind of tracer emission. Results from our initiel tests will therefore be gubject to comparison against the diffuslve attachment models of Greenfield (1957), Junge (19558), and others (e.g-, Goldsmith, et al, , 1963).

\section{Frocedure}

Our plan is that the tracer dispensing aircraft, operated by weather Science, Inc, of Norman, Oklahoma, will be vectored to an operational area selected by synoptic weather criteria for each operational day. our prime target is centered upon The University of Michigan station at Chickasha, Oklahous.

The alrcraft wil crulse so as to intercept promlsing convective storms In an area about 30 min upstream from the target. The operators will select a suitable convective aystem and will notify MSSL and The University of lichig an station by radio of their selection, time, and place of initiating tracer emission, and probable trajectory of the system and path of its rain streak. Two light mobile units will be dispatched to place movable samplers in predetermined patterns (see Figures 7,8 , and 9) so as to intercept the tracerlabeled rain at the ground. These undts will then colject the sampleg immediately following the passage of the subject rainstorm or shower.

\section{e. Amount of Tracer, Duration of Entssion}

The prinoipal backeround of indium is expected to be that naturally present in soils and hence in airborne dust. This is estimated from general earth crust abundance figures to be nearly the same as the soll abundance of ailver. The background of stlver in natural rain and snow has been estimated by E. Bollay Associates, Inc. * at about $2 \times 10^{-11} \mathrm{gm} / \mathrm{ml}$ of water. Considering that the atmospheric burden of silver is probably enhanced considerably by the comercial use of atlver and by its application in cloud seeding experiments, we anticipate that the background of indtum in the atmosphere may be a factor of 5 to 10 lower than that of silver.

Inasmuch as we can measure $5 \times 10^{-10}$ gun of In within $+10 \%$ error by the technique described above, we conclude that an indium concentration of $3 \times 10^{-11} \mathrm{gm} / \mathrm{ml}$ introduced as tracer will be adequate to insure significant

\footnotetext{
*E. Bollay Associates, Inc., 1965. "Meutron Activation Analysis of Silver Content in Precipitation Samples," Final Report, Contract 14-06-D-5573, U.S. Dept. of Interior, Boulder, Colorado.
} 
raeasurements above beckground for samples of at least 1000 ml. To estimate the totai amount of indiun needed for an experiment, we choose a design storm of $10 \mathrm{n} \mathrm{mi}$ diameter moving at $30 \mathrm{kt}$, and we plan for tracer emission at a constant rate for $20 \mathrm{~min}$ In this time the storm deposits rain over an area of $100 \mathrm{n} \mathrm{mi}^{2}$ to $\mathrm{an}$ average depth of $20 \mathrm{~mm}$. The totel volume of vater is therefore $6.9 \times 10^{12}$ ml. Uniform concentration of $3 \times 10^{-11} \mathrm{gm} / \mathrm{ml}$ of indium therfore requires a total of $207 \mathrm{gm}$ of indium. An emission rate of $10 \mathrm{gm} / \mathrm{min}$ for 20 min gives this total within reasoneble tolerance.

Pyrotechnic flares capable of emitting 19 to $22 \mathrm{gm} / \mathrm{min}$ of $\mathrm{InCl}_{3}$ (equivalent to Io to $11.6 \mathrm{gm} / \mathrm{min}$ of $\mathrm{In}$ ) are therefore specifled for the experiments. Materials for a total of rive such tests have been ordered for the 1967 fleld program (May 1 - Jume 15).

3. Tracing By Balloon-Eorne Radar Transponder

Weather Science, Ine., has developed a no-lift balloon-borne radar transponder which can be ejected from the same plane that will dispense the vaporized Incly. It 16 planned that this balloon tracer will be placed near the center of the initial $\mathrm{InCl}_{3}$ plume and will be followed by means of NSSL rader, thus giving an independent estimate of the trajectory of the indium tracer. We anticipate that this complementary information will be of great value in interpreting our data in terms of the storm dynamics. 


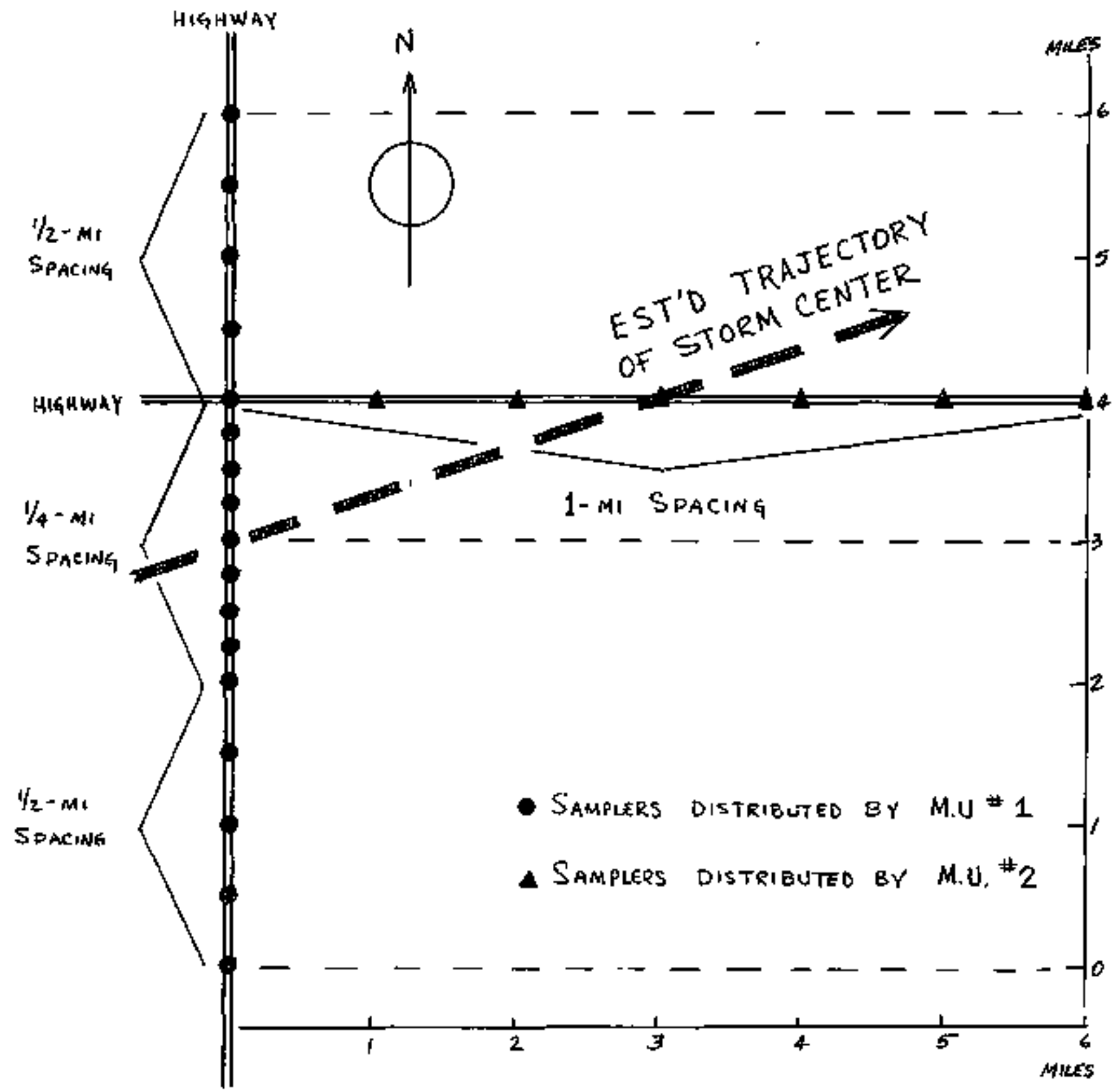

Moblle Unit \#1 distributes 17 samplers along a-s highway near the central target, usiag $1 / 4-m i$ epaeing for 1 gai eacb side of the egtimated storm trajectory and $1 / 2-m 1$ spacing for 2 mi adpitional distaned North and South of the trajectory; Nobtle Wnit of should probably astist \#1 during the flrst 15 min of operations and then proceed to set samplers as indicated at 1-mi intervals along the E-W hlghway.

Figure 7. Use of mobile untts (2) with portgble samplers, example 1. 


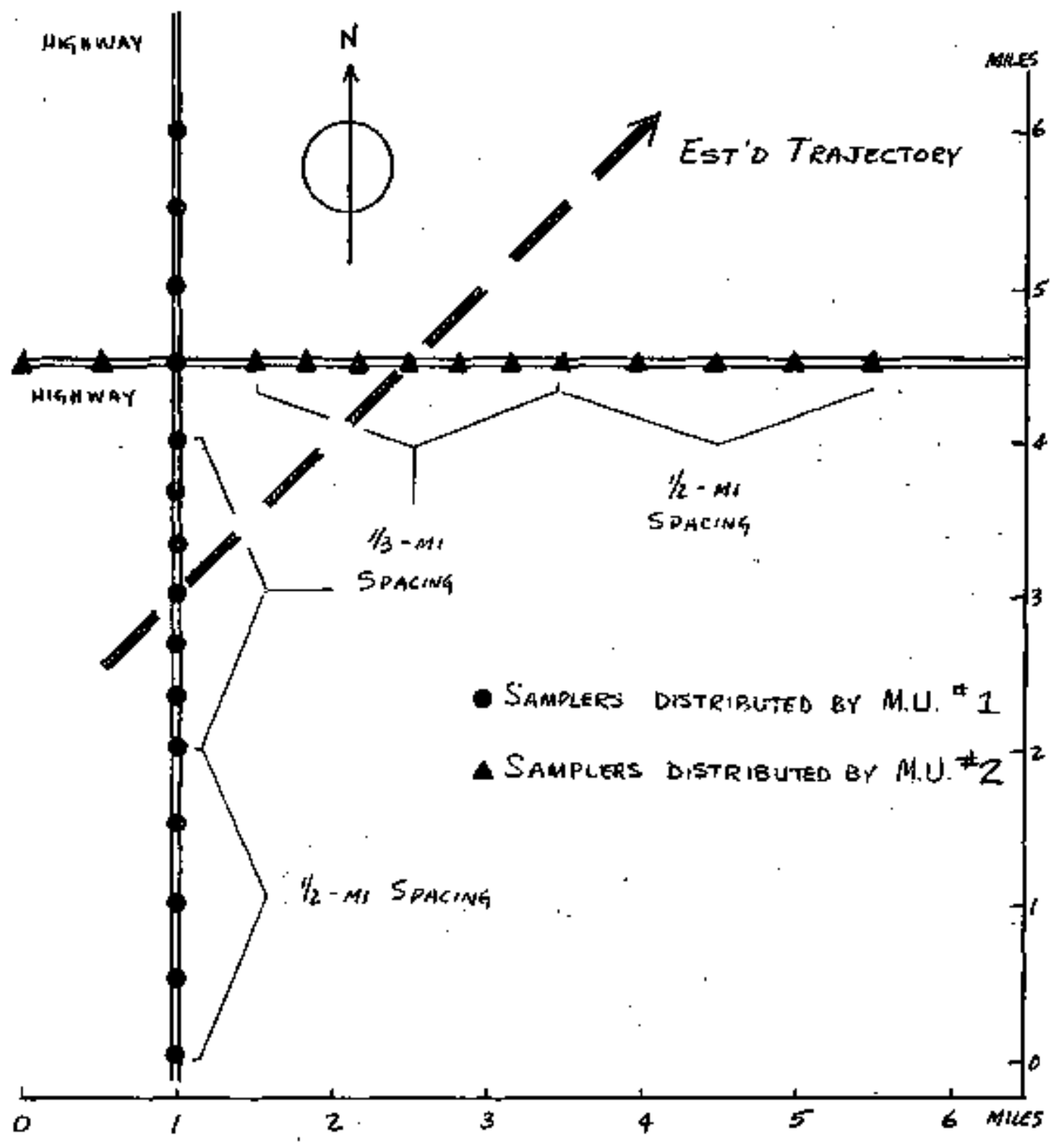

Becsuse the angle of the atorm trajectory 1s near 45*, sampling patterns on the two bighrays are Biniler and symoletric with respect to the estimated trajectory. Samplers are less closely spaced along H-S highray, but more closely along $\mathrm{s}-\mathrm{w}$ highwsy than in Figure 7 .

Figure 8. Use of mobile units (2) with portable sanplers, example 2. 


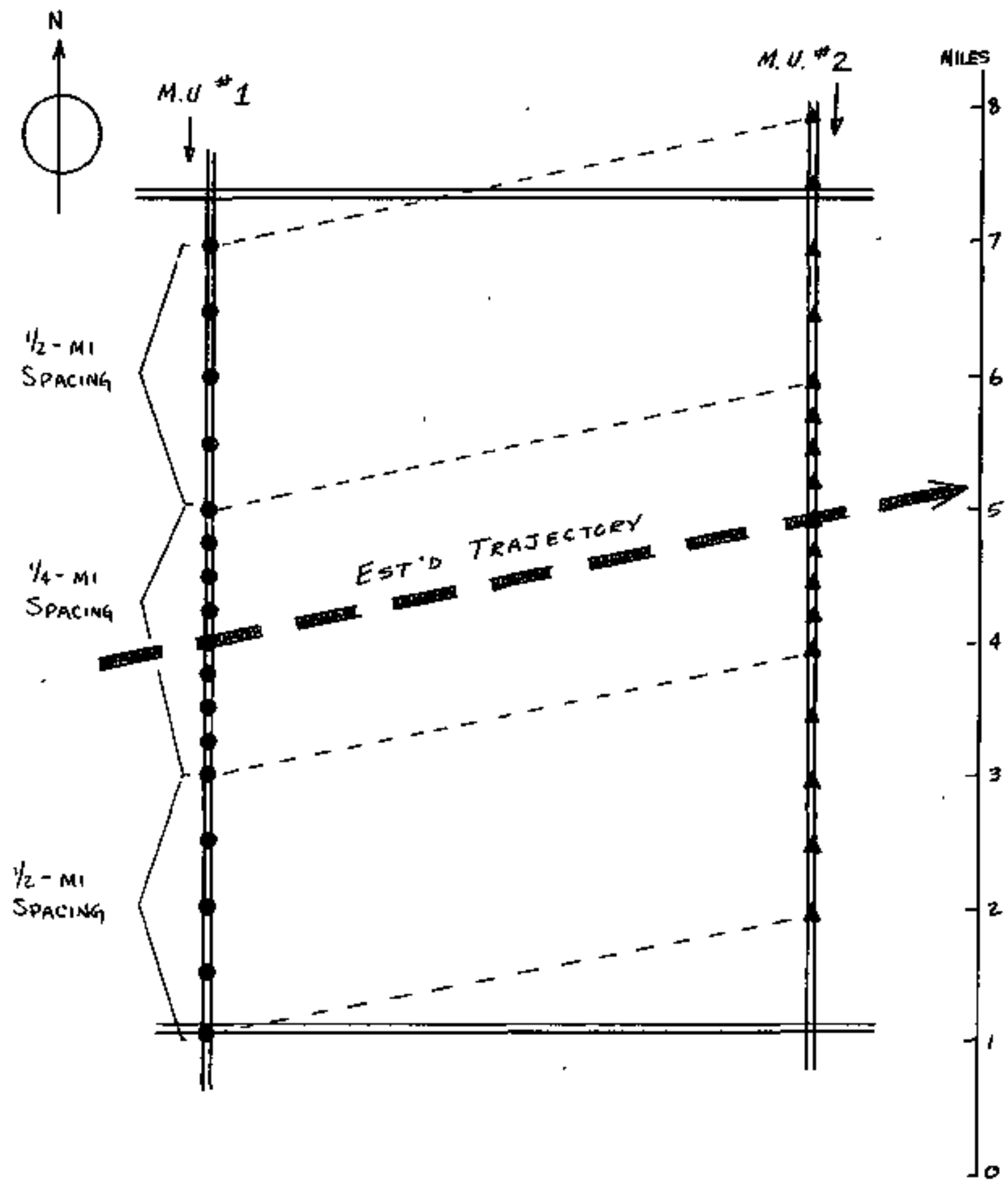

Use of two moblle unitg when estinated storm trajectory does not interaect or approacb a ksable E-W higbway.

Figure 9. Use of mobile units (2) with portable samplers, example 3 . 


\section{MBILE SAMPLING}

The field experinent seasons of 1964, 1965, and 1966 have brought home to us a number of difficulties associated with our limitation to data collection at the fuxed station. We have repeatedy observed storus from the field station, some having much of the character we have aimed to study, which have failed to bring mesurable rain to the fixed station. Because of the nature of convective stor'ds and the narrowness of the rain streaks deposited by them, it is evident that we could collect data more efficientily if we were less firmly anchored to the fixed station. In fairness, it should perhaps be added here that these three years have been unusually dry in the subject area. Nonetheless, in the name of efficiency and effectiveness in moving toward our objectives, it appears that the development of nobile facilities for sampling rainfall should be investigated. We have considered this problem in terms of two basically different kinds of mobile sampling arrangements, one a relatively simple system in which a small unit anght obtain basic rainfell data in a predetermined pattern, and one in which a station quite similar in data-collecting capebility to our present fixed station might be positioned and set into operation in an hour or two from the time of deciding were it could be used to advantage.

\section{A. A FACILITY OF HIGH MOBILITY HAVING THE PRIMCIPAL FUNCTION OF PROGURING RAIN SAMPLES FROM SHOWER SYSTEMS OF INTEREST}

1. Function: To Obtain Sequential Samples in Severe Storms Having Good Time Resolution at a Point

The form suggested for this unit is that of a small van in which personnel could work during a rain storm. The rain collector should be a collapsible funnel of about 5 at collecting area. The catcin of this collector would be piped into the working aree of the van for bottling during storms.' Additional spot data may be recorded in the van, but nain support for weather data should come from ESSA-NSSL and collaborators.

Objectives for this kind of data collection include the following:

a. A systematie study of the variations of contaminants within individual storms. We have noted that the most severe storns contain downdrafta which originate at higher levels than those in less well-organized storms. This is indicated to an extent by our comparisons of the $10 \mathrm{May} 1964$ storm with the showers of 9 May 1964 (Gatz, 1966): In both cases one expects to find that 
the combined effecte of (a) raining out large anounts of contaminant in the early precipitation, and (b) dilution by the more complete dessication of farrising parcels of alr, should leave the high intengity rain fraction relatively pure compared to the lighter shower-onset rain. This was observed in the 9 May 1964 showers, but the heavy rain on $10 \mathrm{May} 1964$ shows only a slight der erease of contaminant concentration between the low- and the high-intensity fractions. We suspect an evaporation process to be meinly responsible and we note that this would systenatically affect the precipitation efficiencies of severe storns.

We believe it inportant to obtain a number of additional bequences of closely resolved samples in severe storms, so as to determine whether such a systematic relationship exists in fact, and to quantify it if possible. Such a mobile unit as this would greatly increase our data-coliection capability for the type of storme in question.

b. The collection of hail as a special additional component of sampling data. By virtue of the special conditions under which hail is formed, we anticlpate that the melt-water from hail should show relatively little effect of evaporation, and hence should enable us more closely to estimate the concentration of contaminants in the eloud water representative of the subcooled and frozen parts of the storm cloud. Taken in relation to the other components of our analysis, we belleve that these data will prove helpbul in our effort to evaluate the water budgets and precipitation efficiencies of hall-producing stortus.

2. Function: To Obtain Distributed Samples Jsing Fortable Samplers in Con. trolled Trecer Studies

This is the function we have planned for our mobile units in the present pilot experiments with indium tracer (see Section II. D.)

It 1 serheps appropriate to polnt out that the highly resolved sequential samples just previously discussed (Sections III.A.I, a and b) should contribute greatly to the interpretation of the distributed samples if the large collector were placed near the center of the diatributed collectors. We feel it may be rost appropriate to combine functions 1 and 2 in one unit for futiure experiments.

An additional data component may be procured by the use of soil samples before and after a tracer-innoculated rainfall. At this point we have not worked out the rather complex chemicel procedures required for adequate analysis of soil samples. As a result, it is not entirely clear whether this component of data will be particularly efficient in producing an information return on the investment of analytical effort. We do plan in the current series of test to acquire some soil aanteles for subsequent analyais an part of our feasibility studies. 
B. A COMPREHENSTVE RAIN-SAMFLING AND OBSERVIFG PACILITY OF LESSER MOBILITY, CAPABLE OF OFERATING OVER AN EXTENDED ARBA IN ASSOCIATION WITH SUITABLE RADAF COVFRAGE AND OTHER COMPLEMENTAKY SUFFORT BY OTHERS

Briefly described, the unit we have considered in thia category would be a semitrailer-trector unit having some enclosed instrumentation-work space (of order $8 \mathrm{ft} \times 8 \mathrm{ft}$ ) and some open flat-bed area. We would equip this unit with basically the same instrumentation as that at our fixed field station at Chickasha, Oklahome (Dingle and Gatz, 1964; Gatz, 1966). This includes a large (5 $\mathrm{w}^{2}$ ) rain-collecting funnel, a raindróp-size spectrometer, a tipping-bucket rain gauge and an anemometer-wind vane assembly, along with the necessary electronics and recording equipment. Additional apecialized instrumentation should be considered, for the recording of electric field intensities, and the messurenent of condensation nuclei.

The unit should be of basic importance to a number of mejor research efforts involving the study of rain. In this connection, we have discussed briefly the prospect of encouraging a broad interest in its developnent as an MCAR faclitity. In that event, the comprehensiveness of the complementary data-gathering progrem in any field project utilizing this facility would be an important consideration. It is clear that raln data, though of value in themselves, require great deal of supporting evidence for their proper interpretation. Thus, calibrated radar, giving PPI and FHI presentations, a network of surface atations, nearby and frequently taken rawinsonde data, and other components required for precise meso-analysis of the rainstom systems should be avalable to derive the most benefit from the specialized rain data.

Use of guch a unit in conjunction with the National Hurricane Research Froject, and with projects such as Hailswath and Whitetop is envisioned. To deternine interest and develop the idea, it may be fruitful to set up a conference of those most immediately concerned together with NCAR fecilities personnel during the summer or fall, 1967.

\section{COMMNICATIONS}

The effective use of mobile field units requlres an adequate comonications systen. This spring, we are trying an FM radio system in coordinating field operations with NSSL radar and the tracer-emitting aircraft. Useful information and experience will be gained from these pilot experiments. 


\section{PRESENTATIONS AND PUBLICATIONS}

\section{A. PRESEMLATIONS}

Since our last report (c00-1407-10) we have reported our work and our plans at a number of conferences. These and their subject content are briefly as follows:

1. Conference on Tracer Expeximents, Sponsored by the AEC Germantown, wa., 27-20 September 1966. Gatz attended; Dingle was forced by illness to cancel the trip at the last minute.

Our projected plans for using controlled tracers in severe storms were presented.

2. Conference on Atmospheric Physics, sponsored by the Commission on College Fhyaics, American Fhysical Society, Boulder Colorado, 5-6 January 1967. Dingle participated.

a. Fresentation of a series of research problems, suitable for study as pert of a phrsical research effort in the context of the smell liberal arts college physics department, was made. These problems malnly derive from our efforts on rain scavenging.

b. Opportunity was elso taken to discuss our ideas on mobile rain sampling, and particularly on a mobile rain sampling facility of NCAR, with Nr. William Lanterman and Dr. Harold Baynton of the NCAR Facilitiea Hivision. The concept of this facility has been presented above in section III-B.

3. Annugl Heeting of the Americen Meteorological Society, New York City, 23-26 January 1967. Dingle and Gatz each presented a paper:

Dingle: Air cleansing by rain

Abstract in Bul. AMS, 47, 11, 900, 1966.

Gatz: Low-altitude input of artificlal radiogotivity to a convective storm-nass-budget evaluation

Abstract in Bul. AMS., 47, 11, 900, 1966.

4. Conference of Farticipants in Spring, 1967, Field studies of severe Storms, sponsored by NSSL, Norman, Oklahoma, 13-14 March, 1967.

Dingle attended and presented plans for controlled tracer studieg, as above, Section II-D. 
5. Conference on Fhysical Irocesses in the Lower Atmosphere, sponsored by Department of Meteorology and oceanography, The University of kilchigan and the Southeastern Michigan Chapter, Als., Ann Arbor, Hichigen, 20-22 March 1967. Gatz presented: Fisn water impurities; implications of concentration changes during convective rains. Abstract in Bul. ANS., 48, 1, 24, 1967.

\section{B. FUBLICATIONS}

The following papers have advanced to the deacribed status in regard to publication:

1. Pollens as condensation nuclei by A. N. Dingle J. de Recherches Atmosphériques vol, 2, 2me Ann., Nos, 2-3, pp. 231-8, Reprints avallable.

2. Low-altitude input of artificial radioactivity to a severe convective storm-comparison with deposition by D. F. Gatz. I. Appl Meteor., summer 1967. Galleys returned. Abstract reprinted below.

3. Afr eleansing by rain by A. N. Dingle, gubmitted to J. Atmos. Scj. J Nay, 1967. Abstract reprinted below.

4. Fin water impurities: implications of concentration chenges during convective rains by D. F. Gatz. In preparation. Abstract reprinted below.

\section{c. ABSTRACTS OF PAFERS IN PRESS (Not Yet Avaliable in the Iiterature)}

1. Low altitude input of artificial Radosetivity to a severe convective storm-comparison with degosition by D. F. Gatz.

Abstract: Concentrotions of artificial radioactivity and plant pollens in rain have been found to vary in phase during convective storms. Because pollens are tracers for low-altitude air, this result is most sinply explained by low-altitude input of both pollens and radioactivity in the convective updraft.

The low altitude input hypothesis was tested by mass-budget methods. Comprehensive mesometeorological and radiochemical dats from a segment of the severe squall line in central Okjahoma on $10 \mathrm{May}, 1964$ were used in the analysis. The radiasctivity inflow rate below 650 mb was estimated kinematically using serial soundings in the storm inflow and the concentration of radioactivity in ground-level air. Total input was computed by multiplying the inflow rate by the time required for the storm to cross a network of 10 ground-level rain samplers. 
Comparison of inflow and deposition over the sampler network shows that inflow of airborne radioactivity to the storm at low altitudes can account for artificial radionctivity deposited in the rain.

\section{Air cleansing by rain by A, N. Dingle.}

Abstract: Detailed observations of rain and of the contaminants in sequential rain samples have been assembled for a number of cases, examples of which are presented. The interpretation of these data in the light of the mitrophysics of rain formation and the dynamics of convective systems leads to a hypothetical model of the air cleansing process. The model depends ainly upon (a) the attachment of submieron particles to larger tropospherte particles by diffusion processes prior to rain scavenging, and (b) principle scavenging action attributable to (1) particle-complexes uhich serve as condensation nuclei, and (2) particle-complexes which are collected by impaction of falling raindrops.

3. Ra1n water inpurities: implications of concentration changes during convective rains by D. F. Gatz.

Abatract: Sequential samples of rain, each representing a rainfall depth of $0 . \overline{3}$ to $1.0 \mathrm{~min}$, vere collected and analyzed for their content of artificial beta-radioactivity and plant pollens. A large time variation of the concentrations of the impurities vas observed in each event that gave at least three samples. Generally speaking, the concentrations vary inversely with the rainfall rate, and this relationship prevails vithin showers in a sequence of showers, whether the rain stops between then or not. It is postulated that this pattern of concentration varlationa can be explained on the basis of a low-sititude removal of the contaminant particles.

In the one persistent aevere atorm that was different. The decrease of contaninant concentration just prior to the heasiest rain was much less than is usually observed. This variation is found to be quantitatively consistent with massive evaporation from raindrops in the heavy rain within a deep (10,000 ft) downdraft region, such as that proposed by Browning (1964).

Implications of this massive evaporation in relation to the precipitation effictencles of such storms are discussed. 


\section{FEFEREHCES}

1. Bleeker, W., W. Dansgaard, and W. N. Lablans, 1966. Sonte remarks on simultaneous measurements of particulate contaminants including radioactivity and isotopic composition of precipitation, Tellus, 18, 4, 773-. 785 .

2. Browning, K., 1964. Airflow and precipitation trajectories within severe local storms which travel to the right of the winds. I. Atmos. ScI., 2l, 634-639.

3. Craig, H., 1961. Standard for reporting concentrations of deuterium and oxygen-18 in natural waters. Scrence 133, $1833-4$.

4. Dingle, A. R., and D. F, Gatz, 1964. Rein Scavenging studies-Data Gollection and synthesis. Final Report, Contract No. AT(1)-1)-1370 with v. s. Atomic Energy Comision. CH-1370-1, Dept. of Meteorology and Oceanography, The Untversity of Michigan, Ann Arbor. $18+v 11$ pp.

5. Dingle, A. N., and D. F. Gatz, 1966. Air cleansing by convective rains. I. Appl. Meteorol. , 2, 2, 160-168.

6. Ehhalt, D., K. Knott, J. F Nagel, and J. C. Vogel, 1963. Deuter1um and oxygen -18 in rain water. J. Geophys. Res. 68, 3775-80.

7. Finnegan, W. G., L. A. Burkardt, and F. St. Amand, 1967. The pyrotechnic generation of freezing nuelei. (Abstract) Eul. Aner. Heteorol. Soc., 悦, $1,23$.

8. Gatz, D. F., 1965. Rain Scavenging Studies-Data Analysis, Synthesis, and Interpretation, Progress Report No. 1, Contract No, RT(11-1)-140? with U.S. Atomic Energy Commission. Ch-1407-2, Depertment of Meteorology and Oceanography, The Untverstty of Michigan, Ann Arbor, $35+i 1 j$ pp.

9. Getz, D. F., 1966. Deposition of Atmospheric Farticulate Natter By Convective Starms: the Role of the Convective Updraft as an Input Mechanism. Fh. D. Dissertation, The University of Mchlgan. (Also Scientiflc Report No. 1, Contract No. AT(11-1)-1407, U.S. Atonte Energy Commission, C00-1407-6, The University of Kichigan Dept. of Meteorology and Oceanography).

10. Goldsmith, P., H. J. Delafield, and L. C. Cox, 1963. The role of diffusiophoresis in the scavenging of radioactive particles from the atmosphere. Quart. J. Roy. Meteorol. 5oc., 89, 379, 43-61. 


\section{REFERENCES (Concluded)}

11. Greenfield, S. M. 1957. Fain scavenging of radioactive particulate matter from the atmosphere. ‥ Meteorol, 14, 115-125.

12. Junge, C. E., 1955a. The size distribution and aging of natural aerosols as determined from electrical and optical data on the atmosphere, $\mathrm{J}$. Meteorol. 12, 1, 13-25.

13. Junge, C. E., 2955b. Remarks about the size distribution of natural geposols. In "Artificial Stimulation of Fain," Proc. Fyrst Conf. on . Physics of Cloud and Precipitation Particles (R. Weickmann and W. Smith, eds.), pp. 3-17. Fergamon, New York. (pub1ished, 1957). 